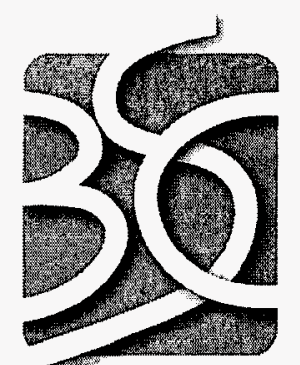

BECHTEL SAIC COMPANYLC

QA: QA 000-30R-WHS0-00100-000-005

March 2005

\title{
Identification of Aircraft Hazards
}

Prepared for:

U.S. Department of Energy

Office of Civilian Radioactive Waste Management

Office of Repository Development

1551 Hillshire Drive

Las Vegas, Nevada 89134-6321

Prepared by:

Bechtel SAIC Company, LLC

1180 Town Center Drive

Las Vegas, Nevada 89144

Under Contract Number

DE-AC28-01RW12101 


\section{DISCLAIMER}

This report was prepared as an account of work sponsored by an agency of the United States Government. Neither the United States Government nor any agency thereof, nor any of their employees, nor any of their contractors, subcontractors or their employees, makes any warranty, express or implied, or assumes any legal liability or responsibility for the accuracy, completeness, or any third party's use or the results of such use of any information, apparatus, product, or process disclosed, or represents that its use would not infringe privately owned rights. Reference herein to any specific commercial product, process, or service by trade name, trademark, manufacturer, or otherwise, does not necessarily constitute or imply its endorsement, recommendation, or favoring by the United States Government or any agency thereof or its contractors or subcontractors. The views and opinions of authors expressed herein do not necessarily state or reflect those of the United States Government or any agency thereof. 
Originators:

T. L. Ashley

K.L. Ashley, Preclosfre Safety Analysis

Checkers:

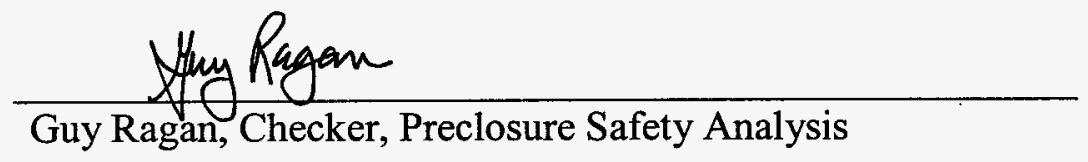

Wigwam Docker

W. Dockers, Quality Engineering Representative

Responsible Manager:

Gems Ruchardsors

D. C. Richardson, Manager, Preclosure Safety Analysis $\frac{3 / 22 / 05}{\text { Date }}$

$\frac{3 / 22 / 05}{\text { Date }}$

22MAR 2005

Date

$3 / 23 / 2005$

000-30R-WHS0-00100-000-005

iii

March 2005 


\section{INTENTIONALLY LEFT BLANK}




\section{CHANGE HISTORY}

\section{Revision}

Number

$\underline{\text { Date }}$

Description of Change

$000 \quad 05 / 03 / 2004 \quad$ Initial issue. Extensive revision of Identification of Aircraft Hazards, TDR-WHS-RL-000001 REV 00, dated 06/13/2002.

001 07/17/2004 Incorporates Nellis AFB information and other miscellaneous comments from Sandia National Laboratory, YMP Licensing, and the YMP Executive Oversight Group.

$002 \quad 11 / 20 / 2004$ Incorporates DOE review comments and refinement of screening criteria. This revision contains extensive changes, therefore, revisions bars have not been used.

003 C3/07/2005 Corrective Action for CR-4992, and improvements as identified in the Engineering Product Review.

004 Correct cover sheet, minor editorial changes and additions for clarity in response to CR-5114.

$005 \quad 03 / 22 / 2005 \quad$ Editorial corrections. 
INTENTIONALLY LEFT BLANK 


\section{CONTENTS}

Page

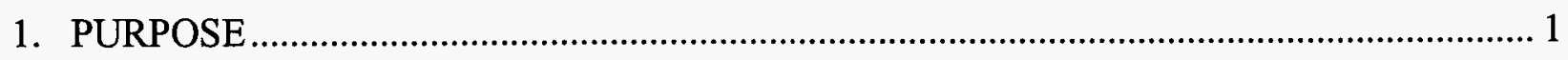

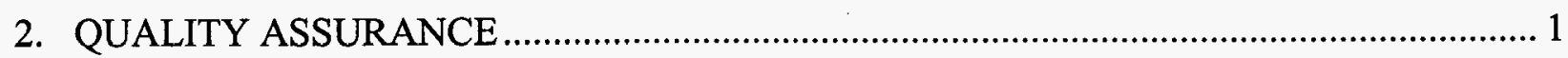

3. USE OF COMPUTER SOFTWARE AND MODELS ……........................................... 1

4. APPLICABLE CRITERIA AND REQUIREMENTS ….................................................... 1

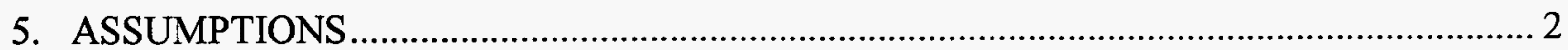

6. AIRSPACE-RELATED FACILITIES, EQUIPMENT, AND ACTIVITIES............................ 2

6.1 Nevada Test Site Airspace ....................................................................................... 10

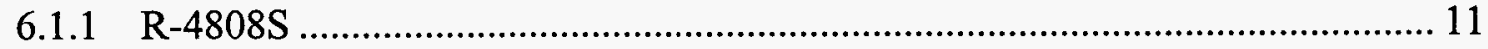

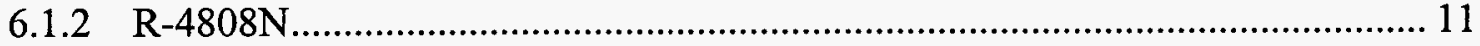

6.2 Military Airspace ………………………................................................................ 11

6.2.1 Nevada Test and Training Range.............................................................. 11

6.2.2 Military Training Routes and Areas ............................................................... 12

6.2.3 R-2508 Complex ………...................................................................... 13

6.3 Civilian, Federal, And Military Airports ...................................................................... 13

6.4 IFR Enroute Low And High Altitude Routes And "Q" Routes....................................... 14

6.5 Ground-To-Ground Missile Testing At Nevada Test Site............................................ 15

6.6 Dropped Objects ..................................................................................................... 15

6.7 Limited Characterization of VFR Flight In The Beatty Corridor ................................. 15

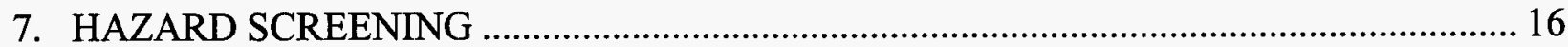

7.1 Screening Criteria ...................................................................................................... 17

7.1.1 Distance from Civilian and DOE Airports.................................................... 17

7.1.2 Distance from Military Airports .......................................................................... 17

7.1.3 Distance from Federal, Military, and DOE Designated Airways ....................... 17

7.1.4 Distance from Airports .............................................................................. 18

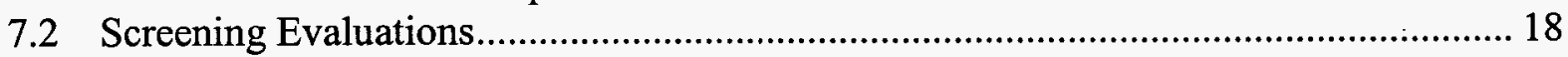

7.2.1 DOE and Military Designated Airspace .................................................... 18

7.2.2 Military Training Routes and Areas ............................................................... 18

7.2.3 Civilian and DOE Airports/Helipads ............................................................ 19

7.2.4 Military Airports ........................................................................................ 20

7.2.5 Federal Airways and Jet Routes............................................................... 21

7.2.6 Military Refueling Routes............................................................................... 21

7.2.7 Flights in the Beatty Corridor Uncontrolled Airspace ........................................ 22

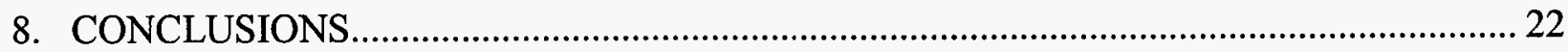

9. REFERENCES …

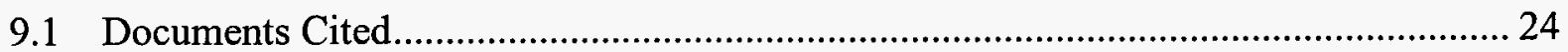

9.2 Codes, Standards, Regulations, And Procedures ........................................................... 25

9.3 Source Data, Listed By Data Tracking Number .............................................................. 26 
APPENDICES

APPENDIX A AIRCRAFT USED IN NTTR

Page

APPENDIX B NEVADA TEST AND TRAINING RANGE

A-1 to A-7

APPENDIX C CIVILIAN, FEDERAL, AND MILITARY AIRPORTS

B-1 to B-9

APPENDIX D

IRF ENROUTE LOW AND HIGH ALTITUDE ROUTES

IN THE REGIONAL SETTING

C-1 to $\mathrm{C}-6$

APPENDIX E CIVILIAN AND MILITARY ACCIDENTS IN THE E-1 to E-4 REGIONAL SETTING AND SELECTED MILITARY ACCIDENTS

APPENDIX F NATURAL BARRIERS (MOUNTAINS)

F-1 to F-4 


\section{FIGURES}

Page

Figure 6-1. Regional Setting Surrounding Yucca Mountain: Includes Military Operations Areas and Military and DOE Restricted Areas ..........................................................................

Figure 6-2. Civilian Airports, Airways, and Navigation Aids in the Regional Setting .................. 5

Figure 6-3. Military Airports, Military Training Routes, and Navigation Aids in the Regional Setting ..................................................................................................................... 6

Figure 6-4. Military Aircraft Accidents in the Nevada Test and Training Range .......................... 7 


\section{TABLES}

Page

Table 6-1. DOE Designated Airspaces ......................................................................... 8

Table 6-2. Military Designated Airspaces ....................................................................... 8

Table 6-3. Military Training Routes ............................................................................ 8

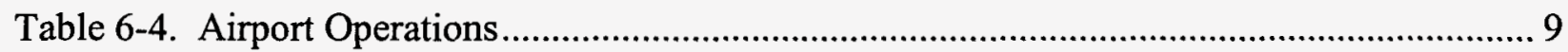

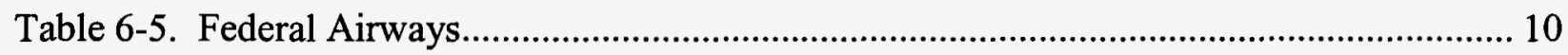

Table 7-1. Civilian and DOE Airport Screening :............................................................. 20

Table 8-1. Aircraft/Airspaces Posing a Potential Hazard to the MGR Identified for Further

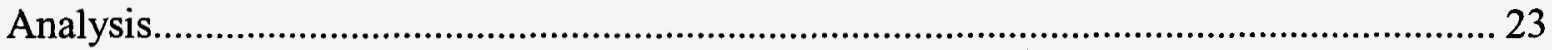

Table A-1. Aircraft In Nevada Test And Training Range Military Operations Areas .............. A-4

Table B-1. Military Training Routes that Access Nevada Test and Training Range ............... B-8

Table D-1. IFR Low and High Altitude Routes..........................................................

Table E-1. Civilian Aircraft Accidents from 1993 to 2003 ..................................................

Table E-2. Air Force Class "A" Accidents in Nevada, 1993-2003 .....................................E-4 


\section{ACRONYMS AND ABBREVIATIONS}

AFB

AGL

AGM

AMSL

ARIP

ARTCC

ATCAA

DOE

EC

ECR

FAA

GPS

IFR

KCAS

KTAS

LATN

MGR

MOA

MTR

NOTAM

NTS

NTTR

RNAV

UAV

USAF

VFR

VORTAC

Air Force base above ground level air-to-ground missile above mean sea level air refueling initial point Air Route Traffic Control Center air traffic control assigned airspace

U.S. Department of Energy

electronic combat

electronic combat range

Federal Aviation Administration

global positioning system

instrument flight rules

knots calibrated airspeed

knots true airspeed

low altitude training and navigation

monitored geologic repository

military operations area

military training route

notice to airmen

Nevada Test Site

Nevada Test and Training Range

area navigation route

unmanned aerial vehicle

United States Air Force

visual flight rules

Very High Frequency Omnidirectional Range Collocated with Tactical Aircraft

Control and Navigation 


\section{PURPOSE}

Aircraft hazards were determined to be potentially applicable to a repository at Yucca Mountain in the Monitored Geological Repository External Events Hazards Screening Analysis (BSC 2004, Section 6.4.1). That determination was conservatively based on limited knowledge of flight data in the area of concern and on crash data for aircraft of the type flying near Yucca Mountain. The purpose of this report is to identify specific aircraft hazards that may be applicable to a Monitored Geologic Repository (MGR) at Yucca Mountain using NUREG-0800, Standard Review Plan for the Review of Safety Analysis Reports for Nuclear Power Plants (NRC 1987, Section 3.5.1.6), as guidance for the inclusion or exclusion of identified aircraft hazards. NUREG-0800 is being used here as a reference because some of the same considerations apply. The intended use of this report is to provide inputs for further screening and analysis of the identified aircraft hazards based on the criteria that apply to Category 1 and 2 event sequence analyses as defined in 10 CFR 63.2 (see Section 4). The scope of this technical report includes the evaluation of military, private, and commercial use of airspace in the 100-mile regional setting of the MGR at Yucca Mountain with the potential for reducing the regional setting to a more manageable size after consideration of applicable screening criteria (see Section 7).

\section{QUALITY ASSURANCE}

This report is subject to the requirements of DOE/RW-0333P, Quality Assurance Requirements and Description, (DOE 2004) because the report determines whether identified aircraft hazards should be considered in subsequent detailed accident analyses that could potentially identify quality-affecting items subject to quality assurance program controls. This report was developed in accordance with LP-3.11Q-BSC, Technical Reports.

\section{USE OF COMPUTER SOFTWARE AND MODELS}

Figures 6-1 through 6-4 were generated by DeLorme Topo USA® 4.0 (๑ 2002 - used with permission) and are presented for illustrative purposes only. The DeLorme software is not subject to the requirements of LP-SI.11Q-BSC in accordance with Section 2.1.2 of the procedure since it is used for illustrative purposes only. Specific citations are provided for other information provided on the maps. No other software routines, macros, or models are used in this report.

\section{APPLICABLE CRITERIA AND REQUIREMENTS}

The regulatory standard for determining event sequences for which the MGR must be designed is 10 CFR Part 63. Based on frequency of occurrence, event sequences are categorized as Category 1, or Category 2, as described in 10 CFR 63.2. Category 1 event sequences are "those event sequences that are expected to occur one or more times before permanent closure" (10 CFR 63.2). Category 2 event sequences are "other event sequences that have at least one chance in 
10,000 of occurring before permanent closure" (10 CFR 63.2). Event sequences that have less than one chance in 10,000 of occurring before permanent closure of the repository are considered beyond Category 2 event sequences and as such, do not require analyses.

\section{ASSUMPTIONS}

5.1 Figures 6-1 through 6-4 are for illustrative purposes only.

\section{AIRSPACE-RELATED FACILITIES, EQUIPMENT, AND ACTIVITIES}

This section describes airspaces within 100-miles of the North Portal at Yucca Mountain. Unless otherwise stated, miles are statute miles. A determination of whether these activities are credible hazards to the MGR and require further evaluation is made in Section 7.

Military, private, and commercial aircraft accidents have occurred in the 100-mile radius surrounding the MGR at Yucca Mountain. The 100-mile regional setting was selected to fully describe the extensive military presence in the airspace surrounding the MGR. It should be noted that the 100-mile regional setting is not intended to infer that airspace-related activities 100 miles from the site would result in credible hazards to repository surface facilities; rather, the airspace within the 100-mile regional setting of Yucca Mountain is used because a number of airborne activities involving military, private, and commercial aircraft, as well as ordnance, and aerospace vehicles use this airspace. Several military operations areas (MOAs) and restricted areas surround the MGR at Yucca Mountain. A number of airports and airfields are also located within the regional setting.

Appendix E summarizes civilian and military accidents in the regional area around the MGR. Eighteen (18) military accidents involving loss of aircraft have occurred within the Nevada Test and Training Range (NTTR) from 1993 to 2003 as seen in Table E-2 of Appendix E (McGregor 2004). Seventy-seven (77) civilian aircraft accidents involving pilot and/or passenger fatalities have occurred in the State of Nevada between 1993 and 2003 as seen in the reference titled, Aviation Accident Database and Synopses, (Ragan 2004b). Nineteen (19) of those accidents occurred in the regional setting with a majority of those surrounding the Las Vegas area airports (Ragan 2004b). Table E-1 of Appendix E lists the 19 accidents. The aircraft accidents are used to help evaluate aircraft crash hazards at the MGR.

Figure 6-1 illustrates the regional setting with terrain contours and latitude and longitude lines. The location of the North Portal at Yucca Mountain ( $36^{\circ} 51^{\prime} 8^{\prime \prime}$ north latitude and $116^{\circ} 25^{\prime} 35^{\prime \prime}$ west longitude) was determined from original survey data (DTN MO0004YMP00017.000) and is shown for illustrative purposes only. Figure 6-2 illustrates civilian aviation facilities, civilian airports, Instrument Flight Rule (IFR) enroute low and high altitude airways, and navigation aids in the regional setting. This figure is otherwise identical to Figure 6-1 except that the contour lines and latitude and longitude lines are removed for clarity. Figure 6-3 identifies military/DOE airfields, navigation aids, and military training routes (MTR). Figure 6-4 identifies military accident sites by location. An assigned accident number (corresponding to Table E-2) and the 
Air Force Safety Center Mishap ID for each military accident in the NTTR (see Appendix E, Table E-2 for additional information) are included in Figure 6-4 for information.

The layout of the NTTR was determined from the Nevada Test and Training Range Chart (NIMA 2001). The layout of the R-2508 Complex was determined from the $2002 R-2508$ Complex User's Handbook (USAF 2001a). The location of airports was determined from the Las Vegas Sectional Aeronautical Chart (NACO 2003a) and Nevada Test and Training Range Chart (NIMA 2001). Information on military accidents was provided by the Air Force Safety Center at Kirtland Air Force Base in New Mexico (McGregor 2004).

The aircraft hazard exposures are discussed relative to DOE designated airspace, military designated airspace, MTRs and areas, airports, and federal airways and jet routes summarized in Table 6-1 through Table 6-5.

Table 6-1 and 6-2 identify DOE and military designated airspaces in the vicinity of the MGR North Portal. Table 6-3 identifies Military Training Routes and Low Altitude Training and Navigation (LATN) Areas and their distance from the MGR North Portal. Table 6-4 identifies civilian and military airports/airfields in the Regional Setting. Table 6-5 identifies Federal Airways (IFR Enroute Low- and High-Altitude Routes) and distance from the North Portal. 


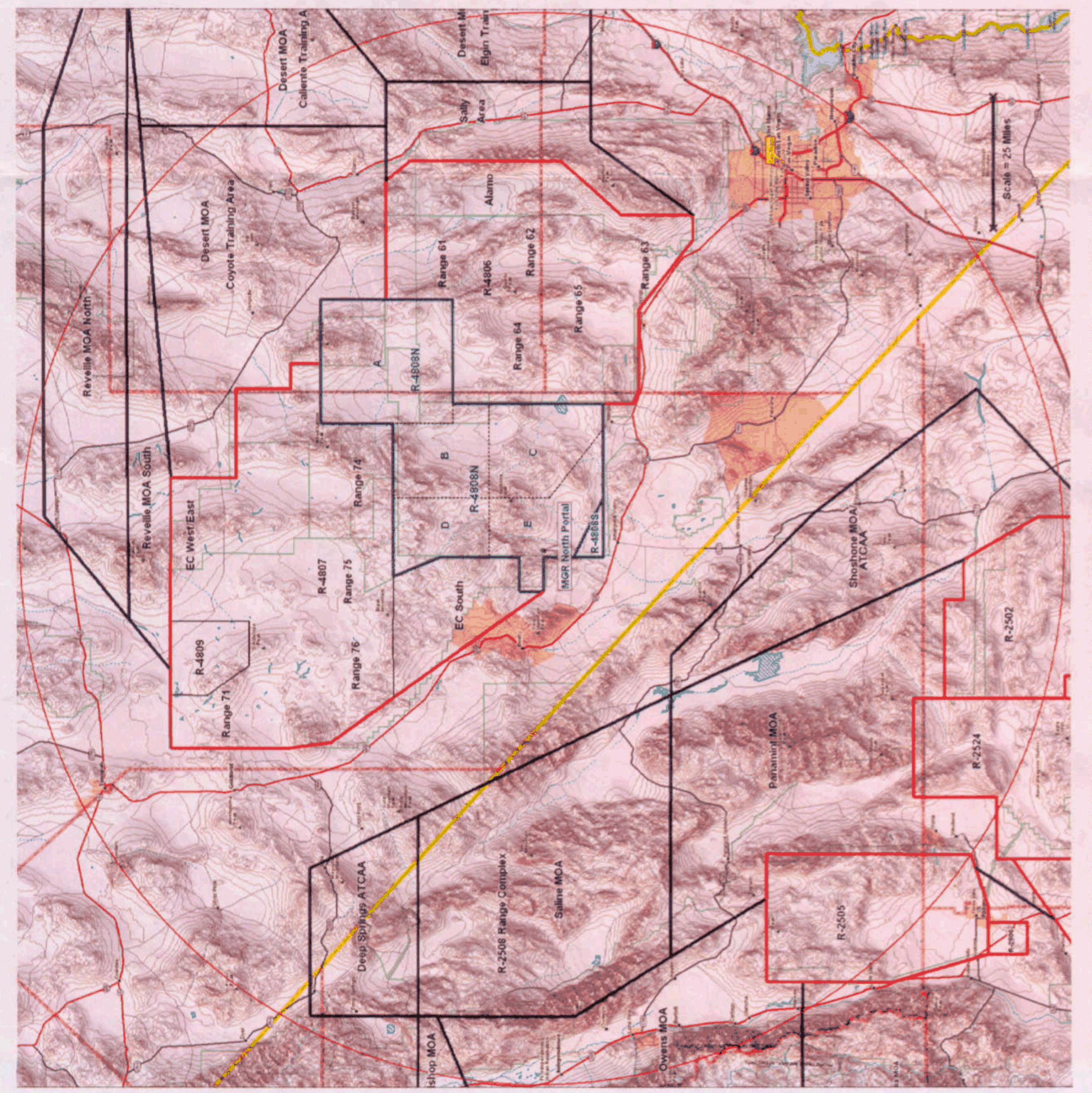




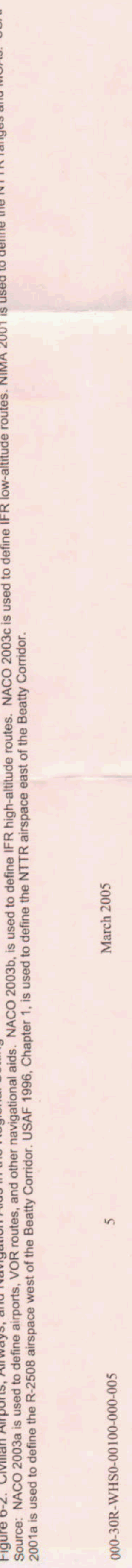



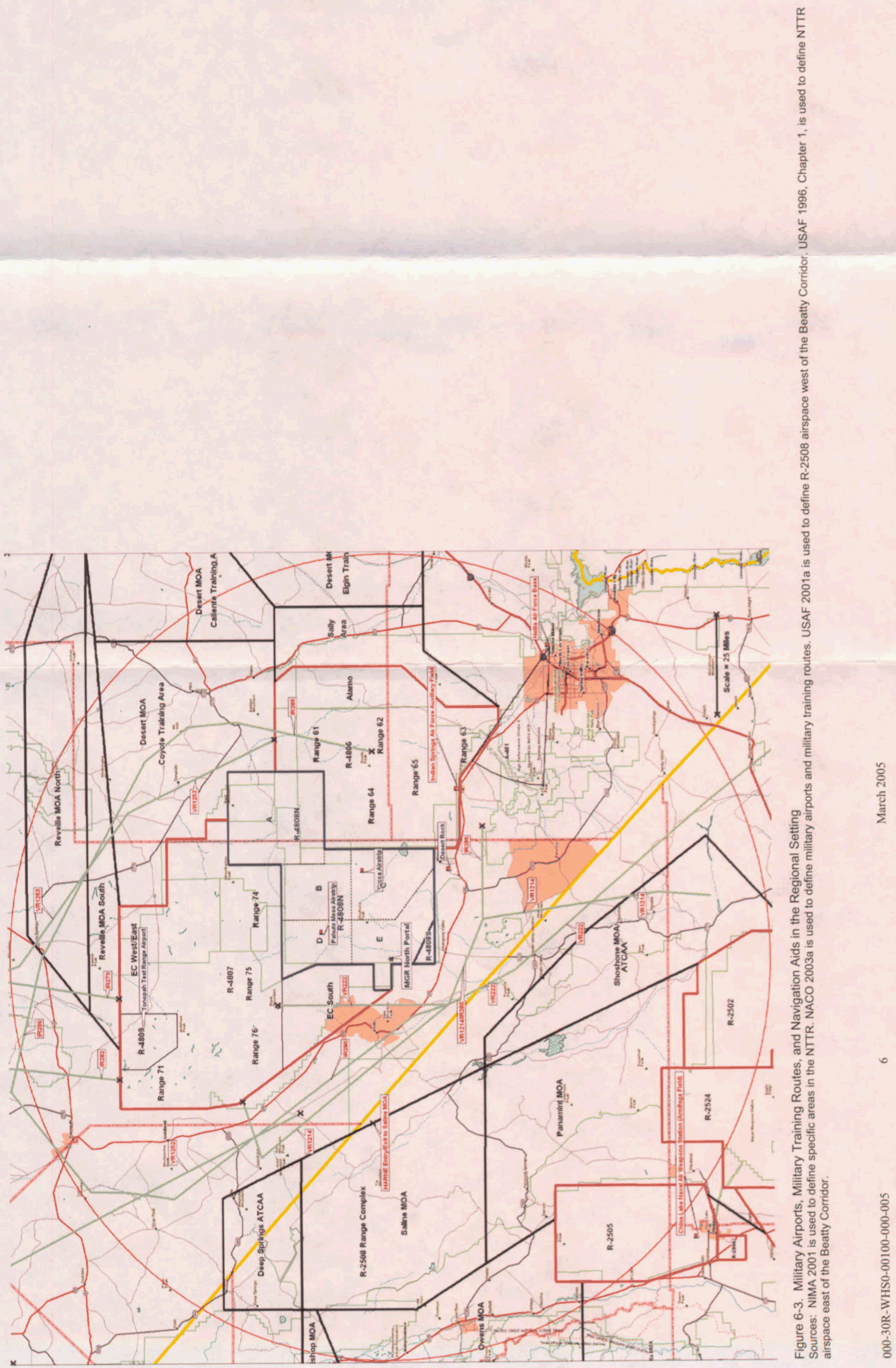


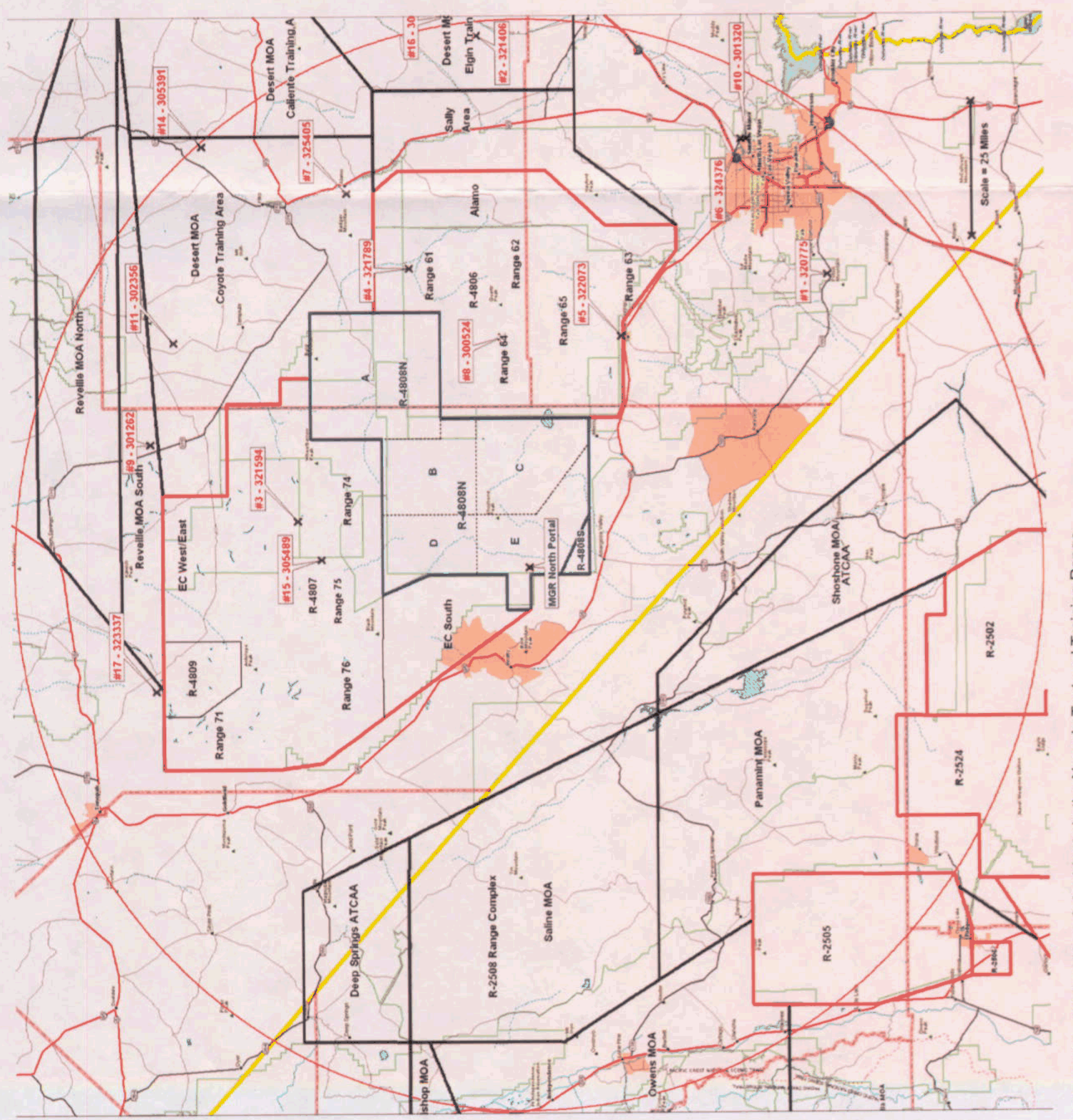

हैं
है 
Table 6-1. DOE Designated Airspaces

\begin{tabular}{|l|c|}
\hline \multicolumn{1}{|c|}{ Designated Airspace } & $\begin{array}{c}\text { Shortest Boundary } \\
\text { Distance to North Portal } \\
\text { (Miles) }\end{array}$ \\
\hline R-4808S & 6 \\
\hline R-4808N (R-4808A) & 29 \\
\hline R-4808N (R-4808B) & 13 \\
\hline R-4808N (R-4808C) & 7 \\
\hline R-4808N (R-4808D) & 10 \\
\hline R-4808N (R-4808E) & Overlays MGR \\
\hline
\end{tabular}

a. Approximate distances to North Portal were determined from NACO 2003a, as measured.

Table 6-2. Military Designated Airspaces

\begin{tabular}{|c|c|}
\hline Designated Airspace & $\begin{array}{c}\text { Approximate Closest } \\
\text { Distance to North Portal } \\
\text { (Miles) }\end{array}$ \\
\hline NTTR & \multicolumn{2}{|c|}{} \\
\hline Reveille (North and South) & 51 \\
\hline Desert & 55 \\
\hline North Range & 58 \\
\hline R-4809A & 28 \\
\hline R-4807 & 5 \\
\hline EC South & \\
\hline South Range & 27 \\
\hline R-4806 & \\
\hline
\end{tabular}

a. Approximate distances to North Portal were determined from NACO 2003a, as measured.

Table 6-3. Military Training Routes

\begin{tabular}{|l|c|}
\hline \multicolumn{1}{|c|}{ Military Training Routes } & $\begin{array}{c}\text { Approximate Closest Distance to } \\
\text { North Portal (airway centerline) } \\
\text { (Miles) }^{\text {a }}\end{array}$ \\
\hline IR-286 & 15 \\
\hline VR-222 & 11 \\
\hline VR-1214 & 18 \\
\hline IR-279 & 72 \\
\hline IR-282 & 77 \\
\hline $\begin{array}{l}\text { Low Altitude Training Navigation } \\
\text { Areas (East) }\end{array}$ & 101 \\
\hline $\begin{array}{l}\text { Low Altitude Training Navigation } \\
\text { Areas (West) }\end{array}$ & 1 \\
\hline $\begin{array}{l}\text { Low Altitude Training Navigation } \\
\text { (Central) }\end{array}$ & 46 \\
\hline
\end{tabular}

a. Approximate distances to North Portal were determined from NACO 2003a, as measured. 
Table 6-4. Airport Operations

\begin{tabular}{|c|c|c|}
\hline Airport & $\begin{array}{c}\begin{array}{c}\text { Approximate Distance to } \\
\text { North Portal } \\
\text { (Miles) }^{\mathrm{a}}\end{array} \\
\end{array}$ & Operations per Year \\
\hline \multicolumn{3}{|l|}{ Civilian $^{\mathrm{b}}$} \\
\hline Alamo & 77 & 230 \\
\hline Amargosa & 38 & 0 \\
\hline Beatty & 21 & 1,005 \\
\hline Calvada Meadows & 46 & 0 \\
\hline Furnace Creek & 37 & 10,200 \\
\hline Goldfield & 75 & 300 \\
\hline Henderson & 94 & 98,500 \\
\hline Heritage & 86 & 0 \\
\hline Hidden Hills & 66 & 200 \\
\hline Imvite & 28 & 0 \\
\hline Jackass Aeropark - Closed as of June 2004 & 15 & 604 \\
\hline Jean & 97 & 20,000 \\
\hline Lida Junction & 61 & 10 \\
\hline McCarran Int'I & 89 & 536,300 \\
\hline North Las Vegas & 82 & 198,611 \\
\hline Shoshone & 61 & 700 \\
\hline Sky Ranch & 86 & 3,000 \\
\hline Stovepipe Wells & 44 & 1,000 \\
\hline Tonopah & 91 & 12,727 \\
\hline Trona & 87 & 7,000 \\
\hline Valley View & 47 & 0 \\
\hline VOC Tech & 92 & 0 \\
\hline \multicolumn{3}{|l|}{ Military ${ }^{c}$} \\
\hline Nellis Airforce Base (AFB) & 90 & 32,400 \\
\hline Indian Springs & 45 & 4,000 \\
\hline Tonopah Test Range & 66 & 200 \\
\hline \multicolumn{3}{|l|}{$D^{d}$} \\
\hline Desert Rock & 27 & 4,700 \\
\hline Pahute Mesa & 18 & 0 \\
\hline Yucca Airstrip & 20 & 0 \\
\hline
\end{tabular}

a. Approximate distances to North Portal were determined from NACO 2003a, as measured.

b. Civilian airport operations: Ragan 2004a.

c. Military operations: Wood 2004.

d. DOE operations: Ragan 2004a. 
Table 6-5. Federal Airways

\begin{tabular}{|c|c|c|c|}
\hline Federal Airway & $\begin{array}{c}\text { Approximate Closest } \\
\text { Distance from Airway } \\
\text { Center Line to North } \\
\text { Portal } \\
\text { (Miles) }\end{array}$ & $\begin{array}{c}\text { Approximate Distance } \\
\text { from Airway Edge to } \\
\text { North Portal } \\
\text { (Miles) }\end{array}$ & Flights per year ${ }^{a}$ \\
\hline$J-9^{b}$ & 86 & 68 & 143 \\
\hline $\mathrm{J}-58 / \mathrm{J}-80^{\mathrm{b}}$ & 82 & 71 & 561 \\
\hline $\mathrm{J}-72^{\mathrm{b}}$ & 88 & 88 & 3,454 \\
\hline$J-76^{b}$ & 88 & 68 & 209 \\
\hline$J-86^{b}$ & 14 & 5 & 3,806 \\
\hline$J-92^{b}$ & 11 & 5 & 79,753 \\
\hline $\mathrm{J}-100^{\mathrm{b}}$ & 86 & 68 & 52 \\
\hline $\mathrm{J}-110^{\mathrm{b}}$ & 41 & $36^{d}$ & 3,415 \\
\hline$J-146^{b}$ & 86 & 68 & 65 \\
\hline$J-148^{b}$ & 95 & 71 & 0 \\
\hline$V-105^{c}$ & 16 & 11 & 1,017 \\
\hline$V-135^{c}$ & 16 & 11 & 534 \\
\hline$V-244^{c}$ & 85 & 80 & 13 \\
\hline$V-394^{c}$ & 88 & 83 & 196 \\
\hline$V-538^{c}$ & 89 & 83 & 0 \\
\hline Q13 ${ }^{\mathrm{a}}$ & 61 & 61 & 0 \\
\hline
\end{tabular}

${ }^{a}$ Route was not established until November 2003 and terminates at the LIDAT fix. Aircraft at this point join J-92 enroute to southeast locations.

"Jet routes (routes that begin with the letter " J") do not have defined widths. Ground controllers continually monitor aircraft flights on jet routes and may divert flights from the centerline as needed to maintain adequate aircraft separation and so as not to intrude in non-authorized/conflicting airspace. Edge distances are measured to the closest restricted airspace location.

'Victor route activity (routes that begin with the letter "V") are only associated with Instrument Flight Rule (IFR) flight operations. Visual Flight Rule (VFR) flights are not reported nor known.

${ }^{d}$ Assumes a maximum width of this east-west route of 10 miles.

Source: Distances determined from NACO 2003a, as measured.

Source: Flights per year determined from Ragan 2002.

\subsection{Nevada Test Site Airspace}

The Nevada Test Site (NTS), operated by the U.S. Department of Energy (DOE) as the nation's on-continent nuclear weapons test site, is protected by restricted areas R-4808N and R-4808S. The NTS airspace R-4808 is controlled by DOE for NTS activities and is not part of the NTTR. Agreements with the U.S. Air Force (USAF) and the FAA allow specific uses by military and civilian aircraft. R4808N is designated as non-joint use by the FAA and the DOE retains exclusive, continuous control. R-4808N is divided into R-4808A, R-4808B, R-4808C, R-4808D, and R-4808E and is controlled by the DOE. R-4808S was created as a joint-use area to permit use by the NTS, Nellis Air Traffic Control Facility, and the FAA Los Angeles Air Route Traffic Control Center (ARTCC) (USAF 1996, Section 1.26.1). 
The DOE allows military aircraft to transit R-4808N over R-4808B, R-4808C, R-4808D and R$4808 \mathrm{E}$ across the NTS for entry/exit into the NTTR ranges north of the NTS. In addition, no-fly zones exist over the Device Assembly Facility at coordinates $36^{\circ} 54^{\prime} 04^{\prime \prime}$ north latitude, $116^{\circ} 02^{\prime}$ $51^{\prime \prime}$ west longitude and Bren Tower at coordinates $36^{\circ} 46^{\prime} 50^{\prime \prime}$ north latitude, $116^{\circ} 14^{\prime} 33^{\prime \prime}$ west longitude (Wood 2004, Attachment 6).

\subsubsection{R-4808S}

Restricted Area R-4808S is used jointly by the NTS, Nellis AFB, and the FAA Los Angeles ARTCC for military and civilian aircraft to overfly the southwest corner on an as-needed basis. Clearance for any aircraft entry into R-4808S is required. The closest boundary of R-4808S to a repository surface facility is about seven miles (NIMA 2001).

\subsubsection{R-4808N}

Within the R-4808N restricted area, Nellis AFB is allowed to use R-4808B, R-4808C, R-4808D and R-4808E to transition aircraft from Nellis AFB to the NTTR and return (Wood 2004). The proposed site for a repository surface facility (i.e., Yucca Mountain) is located in R-4808E.

\subsection{Military Airspace}

The typical aircraft and their missions that are currently or projected to be operational (USAF 1999a, pp. 1-45 to 1-50), are discussed in Appendix A. The aircraft, missions, and aircraft configurations described in Appendix A are intended to be representative of ongoing activities in the NTTR.

Ordnance delivery is only allowed in the 60 series ranges in R-4806 of the South Range and the 70 series ranges in R-4807 of the North Range of the NTTR area. Deployment of air-to-ground missiles (AGM) occurs in the R-4806 (60 Series) and R-4807 (70 Series) ranges as part of the weapons missions of various aircraft. Training exercises using bombs are also conducted in the R-4806 and R-4807 (USAF 2001b, Section 4.3.1). Ordnance is not used in the EC South area to the northwest of the North Portal at Yucca Mountain (NIMA 2001).

Ordnance delivery is only allowed in the restricted areas located near the center or the southern edge of the R-2508 complex (USAF 2001a, Chapter 6). This includes R-2502, R-2505, and R2524 in the Regional Setting.

The range operating agency must ensure that weapon safety footprints exist for all aircraft, weapons, and tactics authorized for a given target and event on the range (USAF 2001b, Section 4.3.1).

\subsubsection{Nevada Test and Training Range}

The NTTR includes airspace, land, and infrastructure dedicated to military uses, as shown in Figure 6-3 (USAF 1999a, Figure 3.1-1, p. 3.1-6). They are composed of the Desert and Reveille MOAs and the restricted areas of the NTTR: R-4806, R-4807, and R-4809. The distances to the North Portal are listed in Table 6-2. 
Military aircraft reach the various MOAs and military designated restricted areas by traveling through the NTS or NTTR restricted areas. The Sally Corridor (part of Desert MOA and immediately east of the 60 Series Ranges) provides the primary access to the MOAs and the military designated restricted areas located north and east of Yucca Mountain.

\subsubsection{Military Operations Areas}

Military airspace includes MOAs and restricted airspace. A MOA is an airspace established to separate or segregate certain military activities from commercial and other civilian air traffic. A restricted area is airspace usually not available to civilian aircraft. Restricted airspace may be designated as joint use, whereby non-participating civil or military aircraft may be routed through this airspace by air traffic control when there is no conflict with scheduled activities. If not designated as joint use, non-participating aircraft are normally not permitted at any time.

The Desert (includes Coyote, Sally, Elgin and Caliente areas) and Reveille MOAs shown on Figure 6-1 are used for conducting air-to-air intercept training, which consists of high altitude operations, abrupt maneuvers, and supersonic flight at and above 5,000 feet above ground level (AGL). The lowest flight altitude, base, of each MOA is 100 feet AGL. The ceiling is up to 18,000 feet above mean sea level (AMSL); however, air traffic control assigned airspace (ATCAA) can be provided on an as-needed basis by the FAA to extend airspace from 18,000 feet AMSL to higher altitudes needed to accommodate flight-training requirements (USAF 1999a, pp. 3.1-4 and 3.1-5). Appendix B provides greater detail of these areas.

\subsubsection{Restricted Areas}

Restricted areas R-4806, R-4807, and R-4809, within the NTTR, are joint use areas. The adjacent DOE restricted area $\mathrm{R}-4808 \mathrm{~S}$ is joint use, and $\mathrm{R}-4808 \mathrm{~N}$ is not joint use. The restricted areas of the NTTR are divided into the North Range and the South Range. These two ranges are separated by the NTS. The restricted areas and range subsections have recently been modified (USAF 1999a, pp. 1-16 to 1-21 and 3.1-3).

The EC South Range of R-4807A is the closest restricted area to the North Portal. EC South Range is an electronic combat range (ECR) located in the southwest corner of R-4807A. Aircrews are prohibited from dropping any ordnance anywhere within the EC South range. The closest boundary of EC South to a repository surface facility is listed in Table 6-2 (NIMA 2001).

\subsubsection{Military Training Routes and Areas}

The military training routes (MTRs) and low altitude training and navigation areas (LATNs) are listed in Table 6-3. Table 6-3 lists the distances to the North Portal. These include the West LATN, the Central LATN and the East LATN and MTRs. Appendix B describes these areas and routes in more detail. The West LATN is closest to the North Portal.

LATN airspace does not include Class B, Class D, and Indian Springs Class E airspace.

The LATN area is an unrestricted airspace established on the sides of the NTTR for A-10s and helicopters to practice random selection of navigation points and low altitude tactical formations between 100 and 1,500 feet AGL and at speeds below 250 knots (USAF 1999a, p. 3.1-8). This 
area is normally used when no airspace is available for this type of training within the NTTR complex. The East LATN is outside the 100-mile regional setting.

MTRs permit military flight training at airspeeds in excess of 250 knots below 10,000 feet AMSL while providing training in low altitude tactics and navigation (USAF 1999a, pp. 3.1-5 to 3.1-8). Five MTRs exist within NTTR restricted airspace as listed in Table 6-3. Routes IR-286 and VR-222 are closest to the North Portal. Descriptions of MTRs are provided in Appendix B.

Two refueling areas are within the 100-mile regional setting, AR-231V and AR-625 (USAF 1999b, Section 4.10).

AR-231V is located to the southwest of the North Portal in Death Valley and approximately 47 miles to the Air Refueling Initial Point (ARIP). This refueling route is used to refuel HH-60 helicopters using C-130 aircraft. Altitude for this refueling route is defined as below FL180 (Flight Level below 18,000 feet).

AR-625 is used to refuel aircraft. It has two altitudes for aircraft refueling. The low track is FL180 to FL210 and the high track is from FL230 to FL250. The closest point to the North Portal is approximately 69 miles and this is an 'Exit' point at $37^{\circ} 12^{\prime}$ north latitude, $117^{\circ} 37^{\prime}$ west longitude (USAF 1999b, Section 4.10).

\subsubsection{R-2508 Complex}

A large area of airspace, referred to as the R-2508 Complex, exists to the west of Yucca Mountain and is composed of MOAs and restricted areas. The R-2508 Complex includes the airspace and associated land presently used and managed by Edwards AFB, National Training Center, Fort Irwin, and Naval Air Warfare Center Weapons Division, China Lake (USAF 2001a, Section 2.3). The distances to the North Portal are listed in Table 6-2. Aircraft from the R-2508 Complex access the restricted areas in the NTTR by the same access routes used by the aircraft from Nellis AFB.

\subsection{Civilian, Federal, And Military Airports}

A number of airports or airfields are located within the regional setting of Yucca Mountain as shown in Figure 6-2 and Figure 6-3. These include civilian, military, and DOE airports as listed in Table 6-4. Appendix $\mathrm{C}$ describes civilian, military, and DOE airports and airfields within a 100-mile radius of the North Portal at Yucca Mountain. Existing facilities range from small, private landing strips to a major international airport. Aircraft activity ranges from 0 to 0.5 million operations per year. The high-volume facilities are located southeast of Yucca Mountain near Las Vegas.

There are 22 civilian airports within the 100-mile radius of the Yucca Mountain North Portal. Jackass Aeropark is the closest civilian airport to the North Portal, while McCarran International and North Las Vegas airports have the most operations per year. The Jackass Aeropark, located in Amargosa Valley, is a public facility owned by the U.S. Bureau of Land Management. The facility has been closed and the FAA has deemed that it be returned to a natural state. The McCarran International Airport, located in Las Vegas, Nevada, and the North Las Vegas Airport, located in North Las Vegas, Nevada, are public facilities owned by Clark County, Nevada. 
There are three military airports within 100 miles of the Yucca Mountain North Portal. A description of these airports is given in Appendix C. Indian Springs is the closest military airport to the North Portal; while Nellis Air Force Base has the most operations per year and Tonopah has the least operations per year. Distance from the North Portal and operations per year are listed in Table 6-4. Indian Springs Air Force Auxiliary Field is located on the southern boundary of R-4806. Nellis AFB is surrounded by the Las Vegas airspace. An advisory area, A-481, is located to the west of Nellis AFB and is used for high-performance climbs and descents to/from Nellis AFB (NACO 2003a).

Small commuter aircraft that fly staff and equipment to and from various national laboratories and the NTS use the Desert Rock Airport. Helicopters based on the NTS also use this airfield. Pahute Mesa Airstrip is currently used very infrequently. The Yucca Airstrip is unpaved and has not been used since 1995 (Langendorf 2002).

Helicopter operations are conducted from helipads at Mercury, Area 6, Area 29, Area 12, and the Field Operations Office in Area 25, as well as Desert Rock Airfield and Pahute Mesa (Langendorf 2002). Most of the helicopter traffic to these areas is out of the Desert Rock Airport.

\subsection{IFR Enroute Low And High Altitude Routes And “Q” Routes}

IFR enroute low altitude routes are established below 18,000 feet AMSL and are normally used by unpressurized propeller aircraft or aircraft not equipped for long-distance, high-altitude flight. Low-altitude IFR routes are designated with the letter " $V$ " and two to three numerical digits and are referred to as "Victor" routes.

Generally overlying those federal airways bordering the NTTR are high altitude routes on which the greatest majority of IFR air traffic conducts flight at or above 18,000 feet AMSL. These routes are depicted on charts with the letter " $\mathrm{J}$ " followed by two to three numerical digits and are often referred to as "Jet" routes. Typical aircraft flying these routes includes airliners, air cargo, corporate jets, and other high-performance aircraft including military aircraft.

Jet routes and Victor routes are flown using ground-based radio navigation facilities; Very High Frequency Omnidirectional Range (VOR) or Very High Frequency Omnidirectional Range collocated with Tactical Aircraft Control and Navigational (VORTAC). Aircraft fly either to or from these directional radio beacons. Area Navigation or " $Q$ " routes were introduced in late 2003 (also known as "RNAV" routes). One Q-route is in the vicinity of the North Portal. These routes are designed for high-altitude aircraft, typically using Global Positioning System (GPS) navigational aids, flying point-to-point. Route Q13 terminates at the "LIDAT" navigation fix approximately 61 miles northwest of the North Portal.

Figure 6-2 depicts the civilian air traffic routes, including the Victor routes and Jet routes that border the NTTR/NTS. Table 6-5 lists the federal airways and jet routes in the regional setting of Yucca Mountain and distances from the North Portal at Yucca Mountain (NACO 2003a, NACO 2003b, NACO 2003c). Victor airways and Jet routes that are near Yucca Mountain are discussed in Appendix D. V-105 and V-135 are the closest airways and J-86 and J-92 are the closest Jet routes to Yucca Mountain, as shown in Table 6-5. 
J-86 terminates at the BTY VORTAC to the north and joins J-110 at the FUZZY navigation fix to the southeast to the BLD VORTAC, where it joins the J-72 route (see Figure 6-2).

J-92 intersects the OAL VORTAC to the north and the BLD VORTAC to the south and continues southeast (see Figure 6-2).

The V-105/135 airway passes to the west of the NTS. V-105 continues to the OAL VORTAC and then on to Reno, NV. Low altitude route V-135 heads northeast at the TEZUM fix and terminates at the Tonopah Airport.

\subsection{Ground-To-Ground Missile Testing At Nevada Test Site}

The last Army Tactical Missile System launch was conducted at the NTS in R-4808A Area 26 in June 2000 (Childers 2002). There are no forecasts as to when future ground-to-ground missile testing could occur (Childers 2002). Missile testing is not evaluated further in this hazard identification.

\subsection{Dropped Objects}

Dropped objects from aircraft occur infrequently. When maintenance crews replace a missing part, it is recorded as a dropped object. Most items are relatively small parts normally classified as screws, antenna, pins, housing covers, light lens, cables, etc (Wood 2004, Attachment 2). In many instances the location of the dropped object is unknown. Maintenance crews determine that a panel or other portion of the aircraft is missing and report the dropped object after the fact. In a few instances the pilot will be aware of a dropped object due to change in flight characteristics and a general location might be determined.

Between 1998 and 2003 an average of 36 dropped objects per year has been reported (Wood 2004, Attachment 2).

\subsection{Limited Characterization of VFR Flight In The Beatty Corridor}

General aviation flights in the Beatty Corridor are not typically tracked by radar, and thus, detailed knowledge of these flights is limited. A survey trip was conducted to characterize the general aviation flights and information from that trip is discussed below (Gorski 2004).

VFR flight in the Beatty Corridor can be characterized as relatively light compared to other areas of the country due to the very low population in the area and a significant fewer number of aircraft registered in the area per square mile. The closest operational airport to the North Portal is the Beatty Airport. The number of aircraft at the Beatty facility is low and in observations over two days in late April 2004 (Gorski 2004), no aircraft activity was seen in the Beatty Corridor. In two days of travel from Tonopah to Pahrump only two single-engine aircraft were seen operating. One aircraft departed Calvada Meadows heading to the west and another aircraft was seen departing Tonopah heading south and then west. During the same trip, a highway construction worker on US 95 just north of Lida Junction was interviewed and questioned as to air traffic in the area. The worker indicated that no small aircraft were seen in the area in the past three weeks while he was manning a highway construction Stop Sign. He did witness one helicopter in the area to the west of US 95 in that timeframe but could not determine if it was civilian or military (Gorski 2004). 
The Airport Manager at Jackass Aeropark characterized VFR flight operations as 'low'. He indicated that the airport was to be shut down June 30,2004. The facility is owned by BLM and leased to the aircraft owners. The runway is in poor condition and he indicated that prop damage from loose asphalt made the use of the airport subject to aircraft caution. He also indicated that the pilots do not fly to the east of highway US 95 due to military operations (Gorski 2004).

Articles in the local papers indicated that the county was considering buying the airport and repairing the runway. However, on June 25, 2004, the Pahrump Valley Times reported that Nye County commissioners had rejected plans to acquire the airport. As stated in Section 6.3, the Jackass Aeropark has shut down.

The Beatty Airport is not manned. A local aircraft owner was interviewed and was asked to characterize the VFR aircraft traffic in the Beatty Corridor. He indicated that there were extensive aircraft operations in the area (in spite of the two days with no activity witnessed). The Beatty Airport has three gliders and they sail to the west of the airport over a mountain that is $6,317 \mathrm{ft}$ high with the surrounding valley at about $3,200 \mathrm{ft}$ above sea level. No glider traffic was witnessed in the area. The owner indicated he does not file flight plans when navigating the Beatty Corridor and instead would use Flight Following Services during poor weather, if he felt it necessary. Flight Following Service is offered on an 'as available' service by the FAA to help VFR pilots navigate (Gorski 2004).

An analysis of the flights in the Beatty Corridor indicates that approximately $16 \%$ of all flights are from general aviation (however, it should be noted that these aircraft are flying IFR - there is no accurate count of VFR flights) (Gorski 2004).

A natural barrier to general aviation flights is the mountainous terrain to the immediate east of US 95 and somewhat further to the west. VFR pilots avoid flights over or near the mountains due to greater turbulence and would prefer to remain over the valley areas especially should a forced landing be required. While a light aircraft can glide great distances under pilot control, pilots in control of their aircraft would immediately glide toward valley locations. The northsouth valley in the Beatty Corridor makes an ideal flight path for VFR flight with many bright sunny days. The area is easy to navigate due to prominent land features resulting in a potentially lower number of documented flights (fewer Flight Plans filed at the Reno Center). Records of Flight Plans are not maintained by the FAA so documented evidence of flights is not available.

\section{HAZARD SCREENING}

A description is presented in Section 6 of airspace-related activities and their associated facilities and equipment within the regional setting extending approximately 100 miles from the North Portal at Yucca Mountain. These activities are evaluated in Section 7 to determine their potential hazard to the MGR.

The process for identifying aircraft hazards that require additional evaluation is to evaluate the potential hazard using conservative criteria based on distance from airports, distance from MTRs, distance from Federal airways, and distance from designated airspace. The hazards that can be clearly shown to pose negligible risk to the MGR due to these factors are screened from further quantitative evaluation. The screening evaluations are performed in Section 7.2. 


\subsection{Screening Criteria}

The following criteria have been selected to screen out activities that pose negligible hazards to a surface facility at Yucca Mountain.

\subsubsection{Distance from Civilian and DOE Airports}

Criterion: Civilian airports with aircraft more than 20 miles from the North Portal at Yucca Mountain do not pose a hazard to that facility.

Basis: Transition from cruise configuration to landing configuration or from take-off configuration to cruise configuration generally occurs within 5 miles of the airport. That is, the aircraft has raised/lowered the landing gear, the flaps are fully withdrawn/extended, and the aircraft has reached airspeed such that the throttle can be reduced in support of noise abatement requirements/normal landing speed. In addition, within the 5 miles, the pilot is in contact with ARTCC/control tower. Tables B-2 to B-5 of DOE-STD-3014-96 (DOE 1996) report crash probabilities per square mile for airports with civilian traffic out to 16 miles from the airport. Crash probabilities per square mile due to civilian airport activity are considered negligible outside this distance (DOE 1996, Section B.3.3). The criterion of 20 miles provides an additional conservative margin for screening from consideration those aircraft disabled while taking-off or landing at nearby airports.

\subsubsection{Distance from Military Airports}

Criterion: Military airports more than 25 miles from the North Portal do not pose a hazard to that facility.

Basis: The maximum distance from an airport with military aircraft where crash probabilities per square mile are reported is 22 miles, as seen in Tables B-6 to B-13 of DOE-STD-3014-96. Crash frequencies due to military airport activity are considered negligible outside this distance from the airport (DOE 1996, Section B.3.3). The criterion of 25 miles provides a conservative margin for screening from consideration those aircraft disabled while taking-off or landing at nearby airports.

\subsubsection{Distance from Federal, Military, and DOE Designated Airways}

Criterion: Federal, military, and DOE designated airways more than 30 miles from the North Portal at Yucca Mountain do not pose a hazard to that facility.

Basis: Screening criterion II.1(c) of NUREG-0800 (NRC 1987, Section 3.5.1.6) indicates that a federal airway, holding pattern, or approach pattern at least 2 miles beyond the site presents an acceptably low risk. NUREG-0800 is used for review of light water reactor nuclear power plants. Although screening criteria established for nuclear power plants are not directly applicable for use at the MGR, the potential hazards associated with aircraft are similar. Therefore, NUREG0800 is being used as a basis for establishing screening criteria to be used for evaluating aircraft hazards at the MGR.

A criterion of 30 miles from the closest edge of the airway, which provides margin to the NUREG-0800 screening criterion, was selected for conservatism. It can be concluded that 
selecting a criterion zone that extends 30 miles from the North Portal at Yucca Mountain will ensure that any airways screened out will have no impact on the cumulative crash probability.

\subsubsection{Distance from Airports}

Criterion: If ten times $(10 \mathrm{x})$ the annual number of operations at an airport is less than $1000 \times \mathrm{D}^{2}$, where $\mathrm{D}$ is the distance in miles from the MGR, operations at the airport do not pose a hazard to the facility.

Basis: Screening criterion II.1(a) of NUREG-0800, (NRC 1987, Section 3.5.1.6) indicates that an airport located a distance $\mathrm{D}$ of more than 10 miles from a site presents an acceptably low risk if the annual number of operations at the airport is less than $1000 \times \mathrm{D}^{2}$, where $\mathrm{D}$ is distance in miles. For example, at a distance of 10 miles, the annual operations must be less than 100,000. As stated in 7.1.3, the use of NUREG-0800 screening criteria is being used as a basis for establishing screening criteria for use with the MGR.

\subsection{Screening Evaluations}

The airspace activities are evaluated within the 100-mile regional setting. Rationale for screening those activities with acceptably low probability of impact to the MGR is provided below.

\subsubsection{DOE and Military Designated Airspace}

The North Portal is located in the R-4808E DOE designated airspace listed in Table 6-1 and depicted in Figure 6-1. Restricted areas R-4808B, R-4808C, and R-4808D have common boundaries with R-4808E. The entire R-4808N area (R-4808A, B, C, D and E) is within the 30mile screening criterion (7.1.3) and, therefore is identified as requiring further evaluation.

R-4808E has a common boundary with the EC South area of R-4807 listed in Table 6-2. Those flights from EC South, entering and leaving R-4808E are captured in the flights near the North Portal. The western portion of R-4806 is also within the 30 -mile criteria and is identified as requiring further evaluation. The rest of the military designated airspaces in the NTTR and China Lake are located at distances greater than the 30-mile screening criterion 7.1 .3 and are screened from further analysis.

In summary, the entire R-4808N area (R-4808A, B, C, D and E), the EC South area of R-4807, and the western portion of $\mathrm{R}-4806$ have been identified as needing further evaluation.

\subsubsection{Military Training Routes and Areas}

Military training routes IR-286, VR-1214, VR-222, and the West LATN are adjacent to R4808E. These routes and training areas are within the 30-mile screening criterion 7.1.3. Military flights below $10,000 \mathrm{ft}$ MSL are conducted on military training routes VR-222, VR-1214, and IR-286. Due to the topographic features in the area and the altitude limitations of the MTRs, these areas, however, are screened from further analysis since military flights below $10,000 \mathrm{ft}$ do not pose a hazard to the MGR (see Appendix F for details). 
The rest of the training routes and LATN (Central and East) areas are at a greater distance than the 30-mile screening criterion 7.1.3 and are screened from further analysis.

LATN West is located approximately 1 mile from the North Portal. Military aircraft flying in LATN West are included in the airspace influencing the aircraft hazards at the MGR facilities identified in Section 7.2.1.

\subsubsection{Civilian and DOE Airports/Helipads}

Jackass Aeropark is the only general aviation airport listed in Table 6-4 that is located within 20 miles from the North Portal. Jackass Aeropark was closed as of June 2004 and is not included as an airport with aircraft hazards for the MGR. The rest of the civilian airports are located more than 20 miles from the North Portal and are screened from further analysis based screening criterion 7.1.1.

The DOE Desert Rock airport is not located within 20 miles from the North Portal and is screened from further analysis based on screening criterion 7.1.1.

Although all civilian and DOE airports have been screened from further analysis based on screening criterion 7.1.1, as additional confirmation, the distance and annual operations are compared with screening criterion 7.1.4.

Screening criterion 7.1.4 references NUREG-0800 (NRC 1987, Section 3.5.1.6), which specifies that an airport located a distance $\mathrm{D}$ of more than 10 miles from a site presents an acceptably low risk if the annual number of operations at the airport is less than $1,000 \times \mathrm{D}^{2}$. For additional conservatism, ten times the annual number of operations is compared to the criterion of $1,000 \mathrm{x}$ $\mathrm{D}^{2}$. Table 7-1 duplicated the information in Table 6-4 for civilian and DOE airports. Column 3 of Table 7-1 shows the NUREG- 0800 criterion of $1,000 \times \mathrm{D}^{2}$. Column 4 , the annual operations at the airport, is well within the criterion for an acceptably low risk listed in Column 3. Likewise, Column 5, ten times the annual operations, is also within the criterion listed in Column 3. Therefore, civilian and DOE airports do not require additional evaluation based on screening criteria 7.1.1 and 7.1.4.

The DOE Area 29 Helipad and Field Operations Office Helipad are both located within the 20mile screening criterion for civilian airports. Piston engine aircraft and helicopters are included in the airspace influencing the aircraft hazards to the MGR facilities and therefore, require further evaluation. 
Table 7-1. Civilian and DOE Airport Screening

\begin{tabular}{|c|c|c|c|c|}
\hline Airport & $\begin{array}{c}\text { Approximate Distance } \\
\text { to North Portal } \\
\text { (Miles) }^{2} \\
\end{array}$ & $\begin{array}{c}\text { NUREG-0800 } \\
\text { Criteria } \\
\left(1000 \times D^{2}\right)\end{array}$ & $\begin{array}{c}\text { Operations per } \\
\text { Year }\end{array}$ & $\begin{array}{c}\text { Screening Criteria } \\
7.1 .4 \\
(10 \times \text { Operations } / y r)\end{array}$ \\
\hline \multicolumn{5}{|l|}{ Civilian $^{\text {b }}$} \\
\hline Alamo & 77 & $5,929,000$ & 230 & 2,300 \\
\hline Amargosa & 38 & $1,444,000$ & 0 & 0 \\
\hline Beatty & 21 & 441,000 & 1,005 & 10,050 \\
\hline Calvada Meadows & 46 & $2,116,000$ & 0 & 0 \\
\hline Furnace Creek & 37 & $1,369,000$ & 10,200 & 102,000 \\
\hline Goldfield & 75 & $5,625,000$ & 300 & 3,000 \\
\hline Henderson & 94 & $8,836,000$ & 98,500 & 985,000 \\
\hline Heritage & 86 & $7,396,000$ & 0 & 0 \\
\hline Hidden Hills & 66 & $4,356,000$ & 200 & 2,000 \\
\hline Imvite & 28 & 784,000 & 0 & 0 \\
\hline Jackass Aeropark & 15 & 225,000 & $\begin{array}{c}604 \\
\text { (Closed June 2004) }\end{array}$ & $\begin{array}{c}6,040 \\
\text { (Closed June 2004) }\end{array}$ \\
\hline Jean & 97 & $9,409,000$ & 20,000 & 200,000 \\
\hline Lida Junction & 61 & $3,721,000$ & 10 & 100 \\
\hline McCarran Int'| & 89 & $7,921,000$ & 536,300 & $5,363,000$ \\
\hline North Las Vegas & 82 & $6,724,000$ & 198,611 & $1,986,110$ \\
\hline Shoshone & 61 & $3,721,000$ & 700 & 7,000 \\
\hline Sky Ranch & 86 & $7,396,000$ & 3,000 & 30,000 \\
\hline Stovepipe Wells & 44 & $1,936,000$ & 1,000 & 10,000 \\
\hline Tonopah & 91 & $8,281,000$ & 12,727 & 127,270 \\
\hline Trona & 87 & $7,569,000$ & 7,000 & 70,000 \\
\hline Valley View & 47 & $2,209,000$ & 0 & 0 \\
\hline VOC Tech & 92 & $8,464,000$ & 0 & 0 \\
\hline \multicolumn{5}{|l|}{$\mathrm{DOE}^{\mathrm{c}}$} \\
\hline Desert Rock & 27 & 729,000 & 4,700 & 47,000 \\
\hline Pahute Mesa & 18 & 324,000 & 0 & 0 \\
\hline Yucca Airstrip & 20 & 400,000 & 0 & 0 \\
\hline
\end{tabular}

a. Approximate distances to North Portal were determined from NACO 2003a, as measured.

b. See Table 6-4 for operations per year for civilian airports.

c. See Table 6-4 for operations per year for DOE airports.

\subsubsection{Military Airports}

The three military airports listed in Table 6-4 are all located at a distance from the North Portal greater than the 25-mile screening criterion 7.1.2. The three military airports, therefore, are not included as aircraft hazards for the MGR. 
Although military airports have been screened from further analysis based on screening criterion 7.1.2, as additional confirmation, the distance and annual operations are compared with screening criterion 7.1.4.

Screening criterion 7.1.4 references NUREG-0800 (NRC 1987, Section 3.5.1.6), which specifies that an airport located a distance $\mathrm{D}$ of more than 10 miles from a site presents an acceptably low risk if the annual number of operations at the airport is less than $1,000 \times \mathrm{D}^{2}$. For additional conservatism, ten times the annual number of operations is compared to the criterion of $1,000 \mathrm{x}$ $\mathrm{D}^{2}$. Table 7-2 duplicated the information in Table 6-4 for military airports. Column 3 of Table 72 shows the NUREG- 0800 criterion of $1,000 \times \mathrm{D}^{2}$. Column 4 , the annual operations at the airport, is well within criterion for an acceptably low risk listed in Column 3. Likewise, Column 5 , ten times the annual operations, is also within the criterion listed in Column 3 . Therefore, military airports do not require additional evaluation based on screening criteria 7.1.2 and 7.1.4.

Table 7-2 Military Airport Screening

\begin{tabular}{|c|c|c|c|c|}
\hline Military Airport & $\begin{array}{c}\text { Approximate Distance } \\
\text { to North Portal }^{\mathbf{a}} \\
\text { (Miles) }^{\text {Nellis AFB }}\end{array}$ & $\begin{array}{c}\text { NUREG-0800 } \\
\text { Criteria } \\
\left(\mathbf{1 0 0 0} \times \mathbf{D}^{\mathbf{2}}\right)\end{array}$ & $\begin{array}{c}\text { Operations } \\
\text { per Year }^{\mathbf{b}}\end{array}$ & $\begin{array}{c}\text { Screening Criteria } \\
\mathbf{7 . 1 . 4} \\
\text { (10 }^{\text {Operations/yr) }}\end{array}$ \\
\hline Indian Springs AFB & 90 miles & $8,100,000$ & 32,400 & 324,000 \\
\hline Tonopah & 45 miles & $2,025,000$ & 4,000 & 40,000 \\
\hline
\end{tabular}

a. Approximate distances to North Portal were determined from NACO 2003a.

b. Operations per Year from Wood 2004, Table 6-4.

\subsubsection{Federal Airways and Jet Routes}

From Table 6-5, the federal airways and jet routes that are outside the 30-mile screening criterion 7.1.3 are screened from further analysis as hazards to the MGR. J-86, J-92, V-105, and V-135 are less than 30 miles from the MGR and, therefore, are included as potential aircraft hazards to the MGR.

For the purpose of this report R-4808S is considered less than the 30 -mile screening criterion and is included as a potential aircraft hazard to the MGR.

\subsubsection{Military Refueling Routes}

The refueling routes defined in Section 6.2.2 (AR-625 and AR-231V) are at a greater distance than any of the distances established in the criteria used to screen air traffic. In addition, significant terrain obstacles are present such that a hazard to the North Portal is extremely unlikely. Due to the distance between the military refueling routes and the North Portal (greater than 30 miles), the refueling routes are screened from further consideration per screening criterion 7.1.3. 


\subsubsection{Flights in the Beatty Corridor Uncontrolled Airspace}

Uncontrolled airspace (also known as 'class G' airspace) exists close to the ground where radar coverage is not normally possible. Air traffic control does not exercise any authority in uncontrolled airspace.

Flights in uncontrolled airspace in the Beatty Corridor are difficult to characterize in terms of number of flights (see Section 6.7). Flights in uncontrolled airspace in the Beatty Corridor are included as potential hazards to the MGR.

\section{CONCLUSIONS}

Airspace-related activities within the regional setting of Yucca Mountain North Portal are described in Section 6. A large regional setting (i.e., 100-mile radius) was selected to fully describe the numerous military and commercial airspace activities surrounding Yucca Mountain. This includes two major military test and training ranges; the NTS; several military, DOE, and commercial airports; and various civilian and military airways and flight corridors. Although the setting is larger than normally considered for NUREG-0800 (NRC 1987, Section 3.5.1.6) evaluations, this report nevertheless provides a comprehensive description of the large military range complex existing within the regional setting. Defensible screening criteria based on airport crash tables in DOE-STD-3014-96, Section B.3.3, (DOE 1996) and crash distance criteria were developed. Based on the evaluation, it can be concluded that airspace activities within these various flight corridors that are located outside of the screening criteria do not pose a credible hazard to the MGR.

Airspace activities were evaluated within this regional setting with defensible criteria and those activities with acceptably low probability of impact to the MGR were screened out in Section 7. The airspace activities not screened out in Section 7 are considered potential aircraft hazards and require crash frequency determination and summation to determine the total frequency of aircraft hazards. The aircraft and airspaces that can potentially pose a hazard to the MGR and that have been identified for further analysis are listed Table 8-1. 
Table 8-1. Aircraft/Airspaces Posing a Potential Hazard to the MGR Identified for Further Analysis

\begin{tabular}{|c|c|c|}
\hline Type of Airspace/Airport & Aircraft & Reference Section \\
\hline \multicolumn{3}{|l|}{ DOE Designated Airspace } \\
\hline $\mathrm{R}-4808 \mathrm{~A}$ & $\begin{array}{l}\text { Small attack/fighter military } \\
\text { aircraft }\end{array}$ & 7.2 .1 \\
\hline R-4808B & $\begin{array}{l}\text { Small attack/fighter military } \\
\text { aircraft }\end{array}$ & 7.2.1 \\
\hline$R-4808 C$ & $\begin{array}{l}\text { Small attack/fighter military } \\
\text { aircraft }\end{array}$ & 7.2 .1 \\
\hline R-4808D & $\begin{array}{l}\text { Small attack/fighter military } \\
\text { aircraft }\end{array}$ & 7.2 .1 \\
\hline $\mathrm{R}-4808 \mathrm{E}$ & $\begin{array}{l}\text { Small attack/fighter military } \\
\text { aircraft }\end{array}$ & 7.2 .1 \\
\hline \multicolumn{3}{|l|}{ Military Designated Airspace } \\
\hline $\begin{array}{l}\text { EC South area of R-4807 and western } \\
\text { portion of R-4806 }\end{array}$ & $\begin{array}{l}\text { Small attack/fighter military } \\
\text { aircraft }\end{array}$ & 7.2 .1 \\
\hline \multicolumn{3}{|l|}{ Civilian and DOE Airports } \\
\hline DOE Area Pad 29 & Helicopters & 7.2 .3 \\
\hline Field Operations Office Helipad & Helicopters & 7.2 .3 \\
\hline \multicolumn{3}{|c|}{ Federal Airways and Jet Routes (includes R-4808S) } \\
\hline $\mathrm{J}-86$ & $\begin{array}{l}\text { Military, commercial and } \\
\text { general aviation aircraft }\end{array}$ & 7.2 .5 \\
\hline $\mathrm{J}-92$ & $\begin{array}{l}\text { Military, commercial and } \\
\text { general aviation aircraft }\end{array}$ & 7.2 .5 \\
\hline$V-105$ & Military and civilian aircraft & 7.2 .5 \\
\hline$V-135$ & Military and civilian aircraft & 7.2 .5 \\
\hline \multicolumn{3}{|l|}{ Uncontrolled Airspace } \\
\hline Class $G$ airspace & $\begin{array}{l}\text { Small piston-engine aircraft, } \\
\text { helicopters, and gliders }\end{array}$ & 7.2 .7 \\
\hline
\end{tabular}




\section{REFERENCES}

\subsection{Documents Cited}

BSC 2004. Monitored Geologic Repository External Events Hazards Screening Analysis. 00000C-MGR0-00500-000-00A. Las Vegas, Nevada: Bechtel SAIC Company. ACC: ENG.20040712.0004.

Childers, M.J. 2002. "Re: NTS Airspace." E-mail from M.J. Childers to R. Morissette, January 31, 2002. ACC: MOL.20020515.0094.

DOD (U.S. Department of Defense) 2002. Area Planning, Military Training Routes, North and South America. AP/1B. St. Louis, Missouri: National Imagery and Mapping Agency.

ACC: MOL.20020510.0069.

Gorski, E.J. 2004. A Characterization of General Aviation Flights and Charter Flights in the Vicinity of the Yucca Mountain North Portal Below 10,000 ft Above Mean Sea Level. [Idaho Falls, Idaho]: Edward J. Gorski. ACC: MOL.20040715.0349.

Langendorf, J.B. 2002. "Re: DOE Airfields." E-mail from J.B. Langendorf to R. Morissette, January 30, 2002. ACC: MOL.20020515.0093.

McGregor, R.M. 2004. "FW: Data Query; Yucca Mountain." E-mail from R.M. McGregor to G. Ragan, February 25, 2004, with attachment. ACC: MOL.20040420.0054.

NACO (National Aeronautical Charting Office) 2003a. Las Vegas Sectional Aeronautical Chart. 69th Edition. Washington, D.C.: U.S. Department of Transportation. ACC: MOL.20040420.0051.

NACO 2003b. IFR Enroute High Altitude-U.S. Washington, D.C.: U.S. Department of Transportation. ACC: MOL.20040420.0049.

NACO 2003c. IFR Enroute Low Altitude - U.S. Washington, D.C.: U.S. Department of Transportation. ACC: MOL.20040420.0050.

NIMA (National Imagery and Mapping Agency) 2001. Nevada Test and Training Range Chart. NTTRCO1. Bethesda, Maryland: National Imagery and Mapping Agency. TIC: 252639.

NRC (U.S. Nuclear Regulatory Commission) 1987. Standard Review Plan for the Review of Safety Analysis Reports for Nuclear Power Plants. NUREG-0800. LWR Edition. Washington, D.C.: U.S. Nuclear Regulatory Commission. TIC: 203894. 
Porter, R.D. 2002. "FW: R-2502N/E AUR." E-Mail from R.D. Porter to J. Ziegler, March 27, 2002, with attachments. ACC: MOL.20020515.0095.

Ragan, G.E. 2002. "To Discuss Information from the FAA Regarding Flights that Pass Near Yucca Mountain." Phone Contact Report from G. Ragan (BSC) to B.W. Shively (FAA), July 31, 2002. ACC: MOL.20021118.0090.

Ragan, G. 2004a. "Airport Master Records for Airports in the Vicinity of Yucca Mountain." Memorandum from G. Ragan to Record Processing Center, April 21, 2004, with attachment. ACC: MOL.20040422.0152.

Ragan, G. 2004b. "Aviation Accident Database and Synopses." Memorandum from G. Ragan to Record Processing Center, April 21, 2004, with attachment. ACC: MOL.20040422.0151.

Shively, B.W. 2002. "Fwd[2]: Re: Information Request." E-mail from B.W. Shively to R. Morissette, March 29, 2002. ACC: MOL.20020515.0092.

USAF (U.S. Air Force) 1996. Weapons Range Management. AFI 13-212, Volume 2/NAFB Supplement 1. [Washington, D.C.]: U.S. Department of the Air Force, Space Missile Command and Control. TIC: 252274.

USAF 1999a. Renewal of the Nellis Air Force Range Land Withdrawal: Legislative Environmental Impact Statement. Washington, D.C.: U.S. Department of the Air Force.

ACC: MOL.20010726.0068.

USAF 1999b. Flying Operations, Local Operating Procedures. NAFBI 11-250. Washington, D.C.: U.S. Department of the Air Force, Nellis Air Force Base. ACC: MOL.20020510.0073.

USAF 2001a. 2002 R-2508 Complex User's Handbook. Washington, D.C.: U.S. Air Force. ACC: MOL.20020510.0072.

USAF 2001b. Range Planning and Operations. AFI 13-212, Volume 1. [Washington, D.C.]: U.S. Department of the Air Force, Space Missile Command and Control.

ACC: MOL.20020510.0065.

Wood, S.G. 2004. "Request for Information Needed from the U.S. Air Force for Aircraft Hazards Analyses for the Yucca Mountain Project (YMP) License Application." Letter from S.J. Wood (USAF) to W.J. Arthur, III (DOE/ORD), May 21, 2004. ACC: MOL.20040624.0165.

\subsection{Codes, Standards, Regulations, and Procedures}

10 CFR 63. 2002 Energy: Disposal of High-Level Radioactive Wastes in a Geologic Repository at Yucca Mountain, Nevada. TIC: 253816

14 CFR 3. Aeronautics and Space: Special Use Airspace. ACC: MOL.20050322.0094 
DOE-STD-3014-96. 1996. DOE Standard, Accident Analysis For Aircraft Crash into Hazardous Facilities. Washington, D.C.: U.S. Department of Energy. ACC: MOL.20010803.0370.

DOE (U.S. Department of Energy) 2004. Quality Assurance Requirements and Description. DOE/RW-0333P, Rev. 16. Washington, D.C.: U.S. Department of Energy, Office of Civilian Radioactive Waste Management. ACC: DOC.20040907.0002.

LP-3.11Q-BSC, Rev. 0, ICN 2. Technical Reports. Washington, D.C.: U.S. Department of Energy, Office of Civilian Radioactive Waste Management. ACC: DOC.20050215.0009.

LP-SI.11Q-BSC, Rev. 0, ICN 1. Software Management. Washington, D.C.: U.S. Department of Energy, Office of Civilian Radioactive Waste Management. ACC: DOC.20041005.0008.

\subsection{Source Data, Listed By Data Tracking Number}

MO0004YMP00017.000. Exploratory Studies Facility and Cross Drift. Submittal date: $05 / 18 / 2000$. 
APPENDIX A

\section{AIRCRAFT USED IN NTTR}


INTENTIONALLY LEFT BLANK 


\section{APPENDIX A}

\section{AIRCRAFT USED IN NTTR}

\section{A.1 Aircraft Operating in Military Airspace}

Aircraft and their missions that are currently or projected to be operational within the NTTR are identified in this appendix. The NTTR airspace used for the different missions flown by each aircraft is discussed. The aircraft, missions, and aircraft configurations represent the ongoing activities in the NTTR.

The Sally Corridor is the primary access path to the MOAs and the military designated restricted areas and lies to the east of the MGR at Yucca Mountain. Some flights return from these areas west of the MGR to the Beatty Corridor. The USAF instructions in Flying Operations, Local Operating Procedures (USAF 1999b, Section 4.10) provide direction for resolving abnormal events within the restricted areas for events occurring in these areas.

\section{A.2 Current Aircraft and Research and Development Aircraft}

Primary aircraft operating in the military airspace are shown in Table A-1 (USAF 1999a, Volume 2, Appendix A.3). Aircraft types operating in the airspace include rotary wing, fixed wing, and remotely operated aircraft (Porter 2002). Aircraft activities performed by the USAF, U.S. Navy, and U.S. Army include simulated combat, combat support, combat service support training, weapons testing, and research and development. The research and development activities may include aircraft types not yet identified. Combat service support training, weapons testing, and research and development aircraft have been identified by the Renewal of the Nellis Air Force Range Land Withdrawal: Legislative Environmental Impact Statement (USAF 1999a, Section 1.6.2), as possible aircraft that may be used in future NTTR operations.

\section{A.3 Projected Aircraft}

Projected aircraft include advanced fighter aircraft and unmanned combat aerial vehicles as discussed in the Renewal of the Nellis Air Force Range Land Withdrawal: Legislative Environmental Impact Statement (USAF 1999a, Section 1.6.2). 


\begin{tabular}{|c|c|c|c|c|c|c|c|c|c|c|c|c|}
\hline $\begin{array}{l}\frac{n}{y} \\
\text { 离 } \\
\text { t }\end{array}$ & 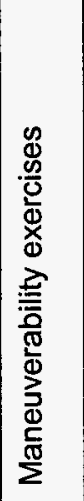 & 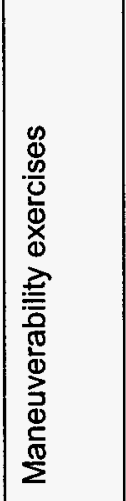 & 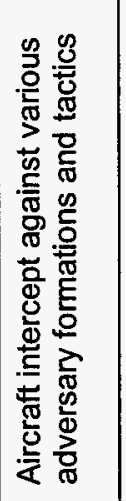 & 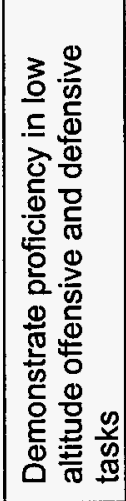 & 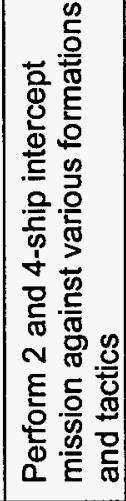 & 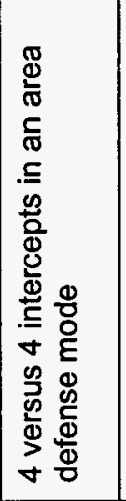 & 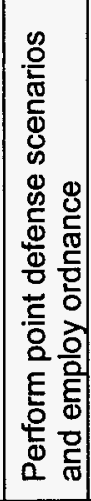 & 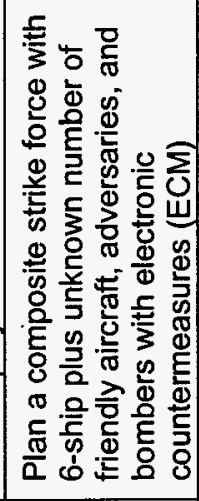 & 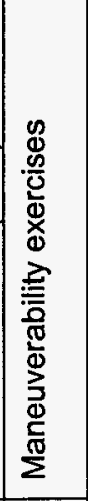 & 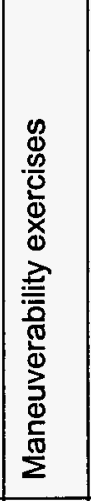 & 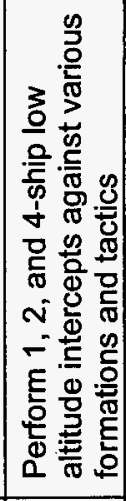 & 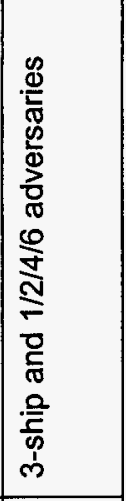 \\
\hline 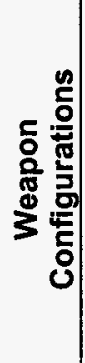 & $\frac{0}{0}$ & 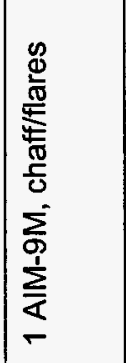 & 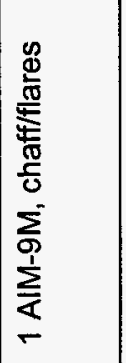 & 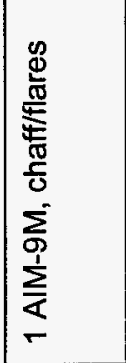 & 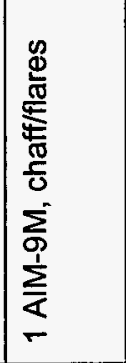 & 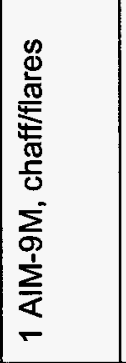 & 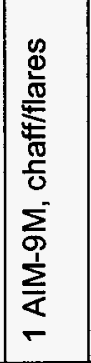 & 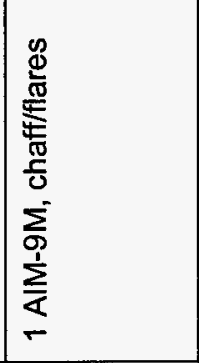 & 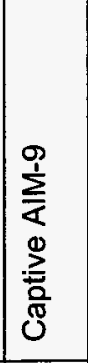 & 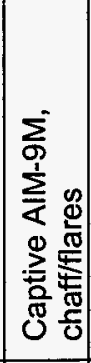 & 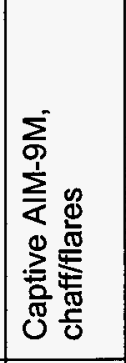 & 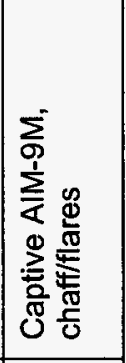 \\
\hline 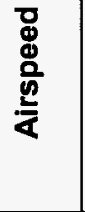 & 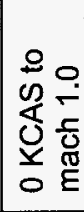 & 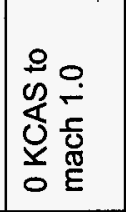 & 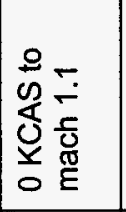 & 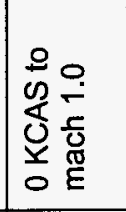 & 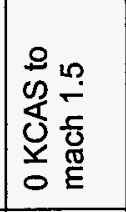 & 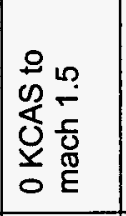 & 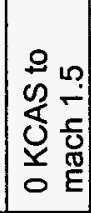 & 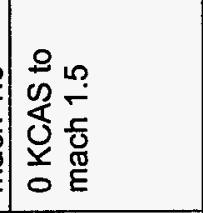 & 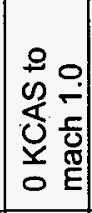 & 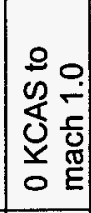 & 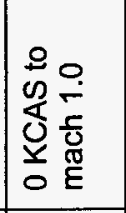 & 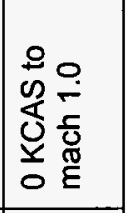 \\
\hline$\frac{\stackrel{0}{0}}{2}$ & 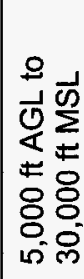 & 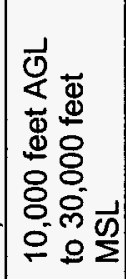 & 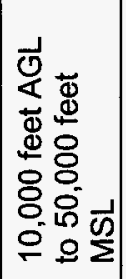 & 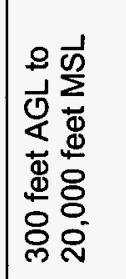 & 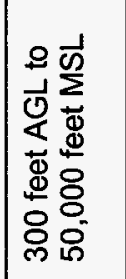 & 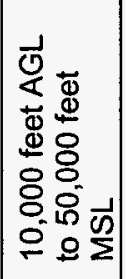 & 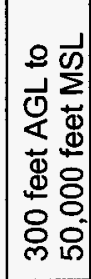 & 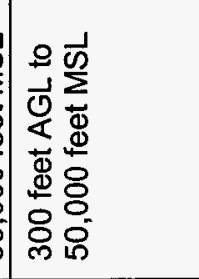 & 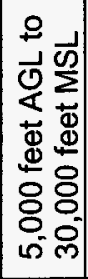 & 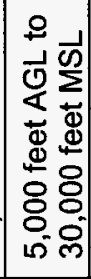 & 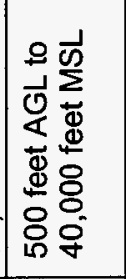 & 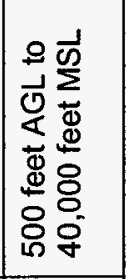 \\
\hline 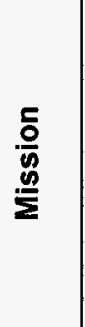 & 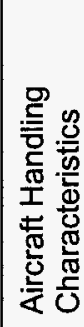 & 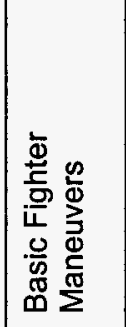 & 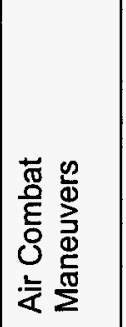 & 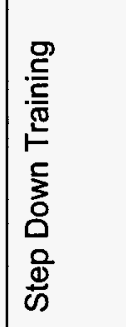 & 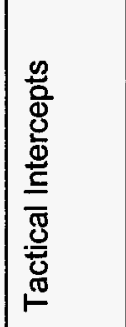 & $\frac{\overline{5}}{\frac{D}{2}}$ & 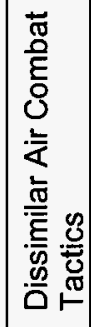 & 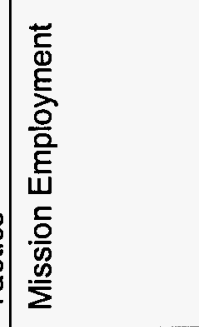 & 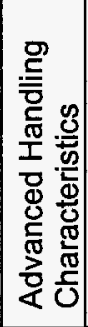 & 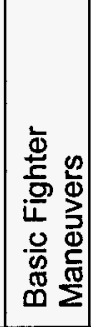 & 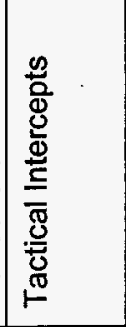 & 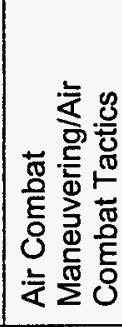 \\
\hline $\begin{array}{l}\frac{\mathrm{T}}{\mathrm{N}} \\
\frac{\mathrm{L}}{\mathrm{\alpha}}\end{array}$ & 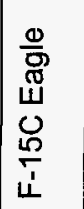 & $\begin{array}{l}\frac{0}{8} \\
\text { W } \\
0 \\
\frac{0}{2} \\
\frac{1}{4}\end{array}$ & 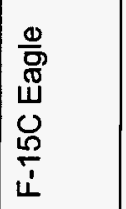 & 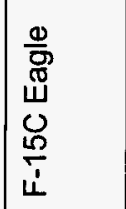 & 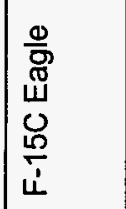 & 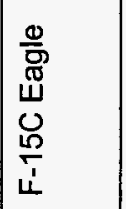 & 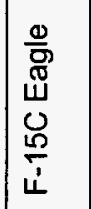 & 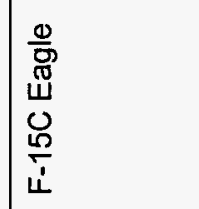 & 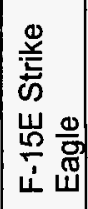 & 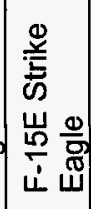 & 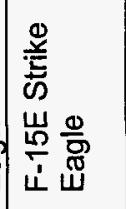 & 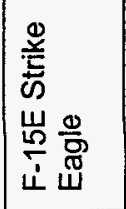 \\
\hline
\end{tabular}




\begin{tabular}{|c|c|c|c|c|c|c|c|c|}
\hline $\begin{array}{l}\frac{n}{y} \\
\frac{y}{0} \\
\qquad\end{array}$ & 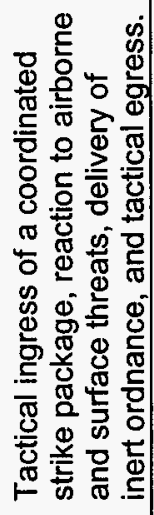 & 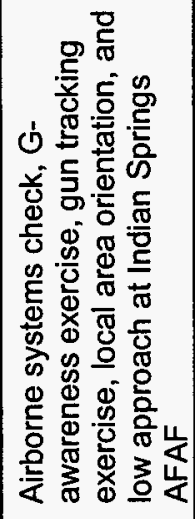 & 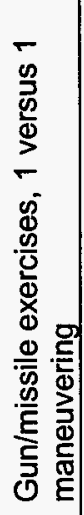 & 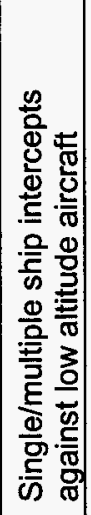 & 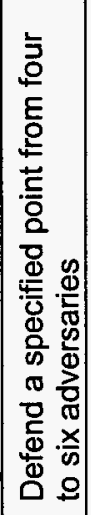 & 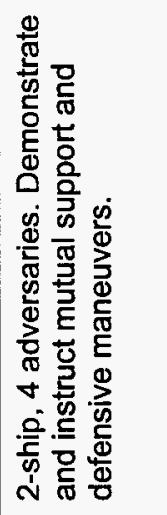 & 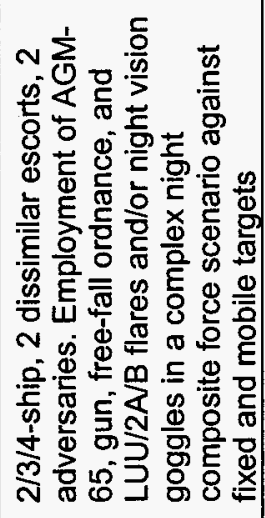 & 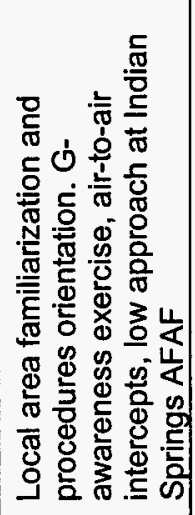 \\
\hline 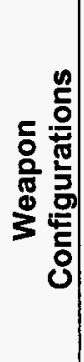 & 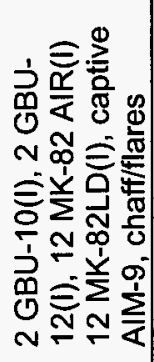 & 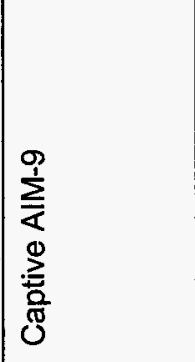 & 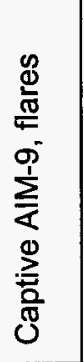 & 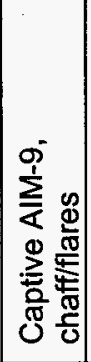 & 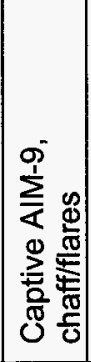 & 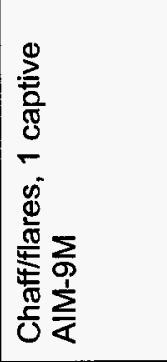 & 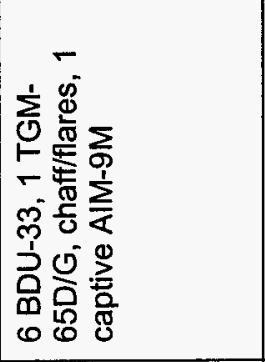 & 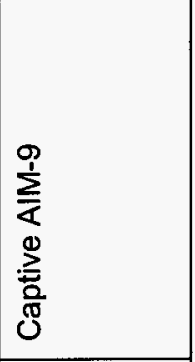 \\
\hline $\begin{array}{l}\text { g. } \\
\frac{0}{n} \\
\frac{.0}{2}\end{array}$ & 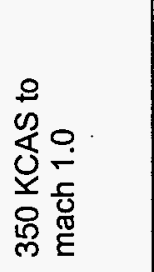 & 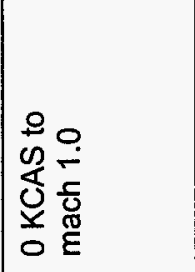 & 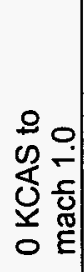 & $\left|\begin{array}{ll}0 & 0 \\
0 & 0 \\
0 & - \\
0 & 5 \\
y & 0 \\
0 & \tilde{y}\end{array}\right|$ & 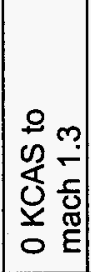 & 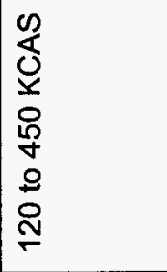 & 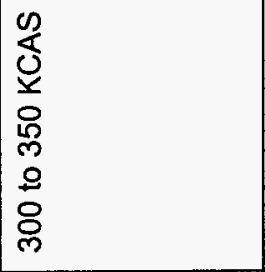 & 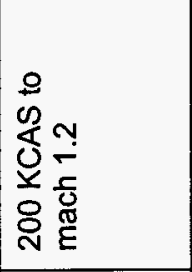 \\
\hline 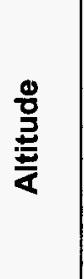 & 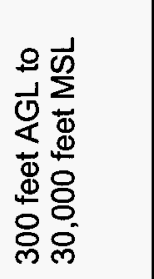 & 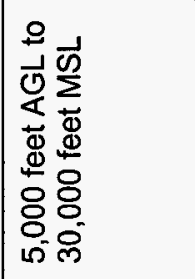 & 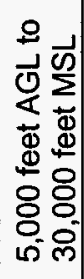 & 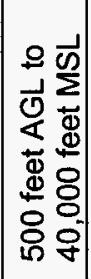 & 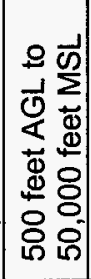 & 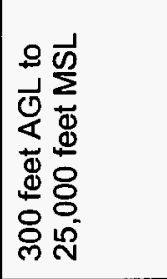 & 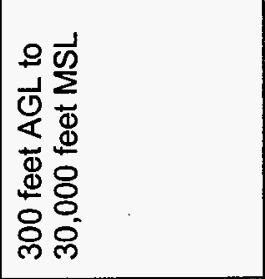 & 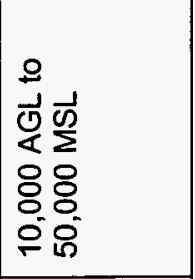 \\
\hline $\begin{array}{l}\bar{o} \\
\frac{0}{D} \\
\frac{\mathscr{n}}{\Sigma}\end{array}$ & 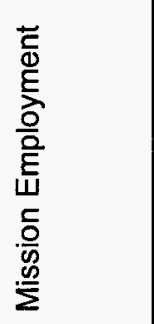 & 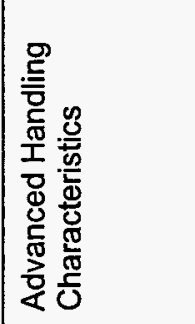 & 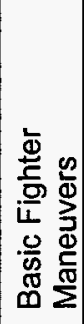 & 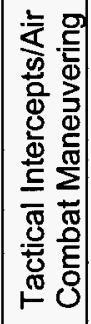 & 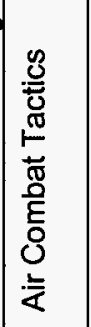 & 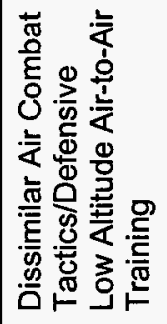 & 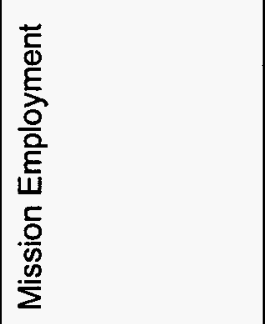 & 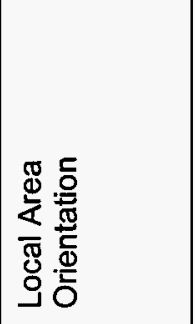 \\
\hline $\begin{array}{l}\frac{\mathrm{T}}{\mathrm{T}} \\
\frac{\mathrm{d}}{\frac{\mathrm{L}}{2}}\end{array}$ & 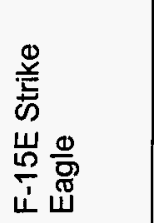 & 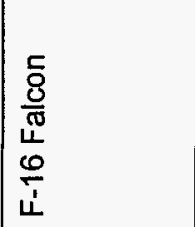 & $\begin{array}{l}\frac{5}{8} \\
\frac{8}{\pi} \\
\frac{6}{10} \\
\frac{1}{1}\end{array}$ & $\begin{array}{l}\frac{c}{8} \\
\frac{0}{\pi} \\
\frac{1}{0} \\
\frac{6}{1} \\
1\end{array}$ & 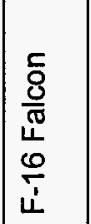 & 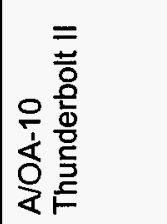 & 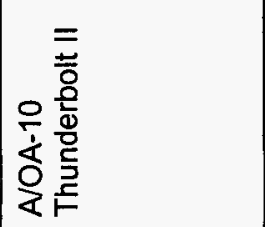 & 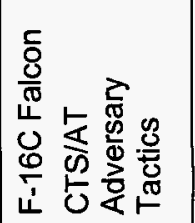 \\
\hline
\end{tabular}




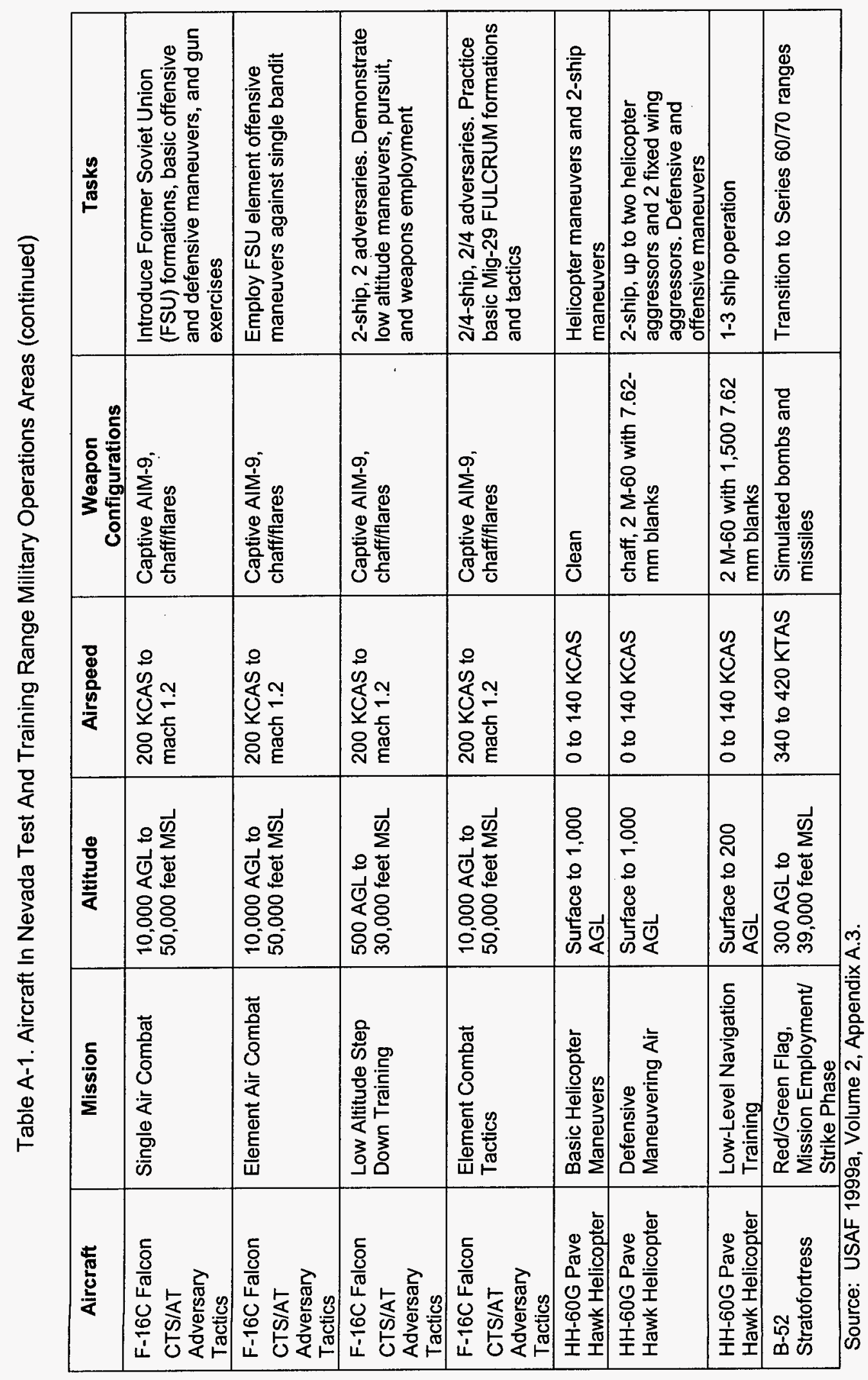


INTENTIONALLY LEFT BLANK 
APPENDIX B

NEVADA TEST AND TRAINING RANGE 
INTENTIONALLY LEFT BLANK 


\section{APPENDIX B}

\section{NEVADA TEST AND TRAINING RANGE}

\section{B.1 Nevada Test and Training Range}

The NTTR includes airspace, land, and infrastructure dedicated to military uses. The lands dedicated to military uses and the airspace of the NTTR are composed of the Desert and Reveille MOAs and five restricted areas of the NTTR: R-4806E, R-4806W, R-4807A, R-4807B, and R4809. R-4809 airspace (including R-4809A) was changed from the DOE as the using agency to the USAF, Headquarters Air Warfare Center, Nellis Air Force Base (AFB), NV, on October 30, 2003 (14 CFR Part 73, Airspace Docket No. 03-AWP-6).

\section{B.1.1 Military Operations Areas}

Military airspace includes MOAs and restricted airspace. Restricted airspace may be designated as joint use, whereby non-participating civilian or military aircraft may be routed through this airspace by air traffic control when there is no conflict with scheduled activities. If not designated as joint use, non-participating aircraft are normally not permitted at any time.

The Desert and Reveille MOAs shown on Figure 6-1 are used for conducting air-to-air intercept training, which consists of high altitude operations, abrupt maneuvers, and supersonic flight at and above 5,000 ft AGL. The base of each MOA is $100 \mathrm{ft}$ AGL. The ceiling is up to 18,000 $\mathrm{ft}$ AMSL; however, ATCAA can be provided on an as-needed basis by the FAA to extend airspace from $18,000 \mathrm{ft}$ AMSL to higher altitudes needed to accommodate flight training requirements (USAF 1999a, pp. 3.1-4 and 3.1-5).

\section{B.1.2 Reveille Military Operations Area}

The Reveille MOA airspace comprises the northern portion of the NTTR and is normally controlled by the FAA's Salt Lake ARTCC. Nellis must schedule use of this airspace in advance since it includes FAA jet routes and federal airways used for east-west transit of IFR traffic (USAF 1999a, pp. 3.1-4 and 3.1-5).

Use of the ATCAA airspace above 18,000 feet AMSL requires 11 days advance notice because of civilian air traffic; therefore, military air traffic is generally located below 18,000 feet AMSL unless large mission employment exercises need additional airspace for staging purposes (USAF 1996, Section 1.2.3.2). The closest boundary of the Reveille MOA is about 71 miles from the North Portal at Yucca Mountain (NIMA 2001).

\section{B.1.3 Desert Military Operations Area}

The Desert MOA is the eastern half of the NTTR and is active with military traffic during daylight hours Monday through Saturday, and by Notice to Airmen (NOTAM) during other hours (USAF 1999a, pp. 3.1-4 and 3.1-5). Training will generally occur between $300 \mathrm{ft}$ AGL and $50,000 \mathrm{ft}$ AMSL and is divided into the following four subsections. 
- Sally corridor is a transition route between Nellis AFB and portions of the NTTR per Weapons Range Management (USAF 1996, Section 1.2.4.2.5). The closest boundary of the Sally corridor to a repository surface facility is about 64 miles (NIMA 2001).

- Elgin is primarily an air-to-air training area and contains the Nellis training range, which, through a system of aircraft transmitters and ground receivers, allows recording of flight maneuvers for real-time flight monitoring and later replay and flight debriefing. It is normally entered and exited via the Sally Corridor. The closest boundary of the Elgin MOA to a repository surface facility is about 88 miles (NIMA 2001).

- Caliente is primarily an air-to-air training area with west entry/exit via Sally corridor and east entry/exit via MTRs or Sally corridor. The Cedar ATCAA overlies the northern portion of Caliente. The closest boundary of the Caliente MOA to a repository surface facility is about 84 miles (NIMA 2001).

- Coyote provides airspace for tactical training maneuvers. The closest boundary of the Coyote MOA to a repository surface facility is about 55 miles (NIMA 2001).

\section{B.2 Restricted Areas}

Within the NTTR, restricted areas R-4806, R-4807, R-4808S, and R-4809 are joint use and R$4808 \mathrm{~N}$ is not joint use. The restricted areas of the NTTR are divided into the North Range and the South Range. These two ranges are separated by the NTS. The restricted areas and range subsections have recently been modified (USAF 1999a, pp. 1-16 to 1-21 and 3.1-3).

\section{B.2.1 North Range}

The North Range is approximately 1.8 million acres of withdrawn land. It contains four unmanned weapons delivery sub-ranges, three ECRs, the Tonopah Test Range, and Pahute Mesa.

A description of the target and threat sites can be found in Weapons Range Management (USAF 1996, Sections C and D) and in Flying Operations, Local Operating Procedures (USAF 1999b, pp 1-22 and 1-23). The sub-ranges are described below (USAF 1999a, pp. 1-16 to 1-21 and 3.1$3)$.

\section{B.2.1.1 R-4807A}

R-4807A includes the 70 Series ranges and the (ECRs) and is divided into several subsections, as described below (USAF 1999a, pp. A-8 and A-9).

- Range 71 is located in the northwest corner of R-4807A and contains aircraft targets. The closest boundary to a repository surface facility is about 52 miles (NIMA 2001).

- Range 74 is located in the eastern portion of R-4807A. The closest boundaries to a repository surface facility are about 32 miles (NIMA 2001).

- Range 75 is located in the central portion of R-4807A and contains numerous targets consisting of missile sites, convoys, signal platoons, air defense artillery units, infrared 
targets, and other array targets. The closest boundary of Range $75 \mathrm{E} / \mathrm{W}$ to a repository surface facility is about 34 miles (NIMA 2001).

- Range 76 is located in west central R-4807A and contains numerous targets consisting of airfields, missile sites, industrial areas, a railroad complex, convoys, command and control centers, and tank arrays designed for infrared training. Live ordnance is allowed on some targets, and inert training ordnance is allowed on all targets. Manned threat emitters are sometimes located in these zones. The closest boundary of Range 76 to a repository surface facility is about 33 miles (NIMA 2001).

- Tolicha Peak ECR is a manned electronic combat threat simulator range located in the southwest corner of R-4807A (USAF 1996, Section 1.19). The closest boundary to a repository surface facility is about 30 miles (NIMA 2001).

- Tonopah ECR is a manned electronic combat threat simulator range located in the eastern portion of R-4809 and the northern portion of R-4807A (EC East and EC West). The closest boundary to a repository surface facility is about 58 miles (NIMA 2001).

- EC South Range is an ECR located in the southwest corner of R-4807A. Aircrews are prohibited from dropping any ordnance anywhere within the EC South Range. The eastern area extends from the surface to 13,000 feet AMSL to allow overlying corridor above 14,000 feet AMSL to transition aircraft from the northern ranges for recovery to Nellis AFB. The closest boundary of EC South to a repository surface facility is about five miles (NIMA 2001).

\section{B.2.1.2 R-4807B}

R-4807B (Pahute Mesa) is used by DOE as an annex to the NTS in support of the nation's nuclear weapons test program, and the USAF uses the airspace for over-flights. Helicopter traffic extends up to 500 feet AGL (USAF 1999a, p. A-9). The closest boundary of R-4807B to a repository surface facility is about 30 miles (NIMA 2001).

\section{B.2.1.3 R-4809}

R-4809 contains EC threat simulators and equipment used by Sandia Corporation for DOE. The TTR Airfield, located within R-4809A, can be used as a divert base for in-flight emergencies (USAF 1996, Section 1.22). The closest boundary of the TTR to a repository surface facility is 58 miles (NIMA 2001). .

\section{B.2.2 South Range}

The South Range is approximately 1.2 million acres of withdrawn land. It contains five weapons-delivery areas (Ranges 61, 62, 63, 64 and 65) (USAF 1999a, Figure 1-7, pp.1-21 and 123). 


\section{B.2.2.1 R-4806E}

R-4806E (Alamo), located west of Sally, is primarily an air-to-air training area with entry and exit via the Sally corridor. It consists, from north to south, of Alamo Alpha, Alamo Bravo, and Alamo Charlie (USAF 1996, Section 1.18). The closest boundary of the Alamo range to a repository surface facility is about 62 miles (NIMA 2001).

\section{B.2.2.2 R-4806W}

R-4806W contains the 60 Series Ranges and is divided into 5 major Ranges that are further subdivided, as described below, that are used for conventional bombing and gunnery testing and training (USAF 1996, Sections 1.4 to 1.9). The closest boundary to a repository surface facility is about 27 miles (NIMA 2001).

- Range 61 is composed of $61 \mathrm{E}$ and $61 \mathrm{~W}$ and is in the northeastern corner of R-4806W. The closest boundary to a repository surface facility is about 49 miles (NIMA 2001).

- Range 62 is composed of $62 \mathrm{~N}$ and $62 \mathrm{~S}$ and is in the eastern section of R-4806W. The closest boundary to a repository surface facility is about 48 miles (NIMA 2001).

- Range 63 is composed of 63 and $63 \mathrm{~A}$ and is in the southeastern section of R-4806W. The closest boundary to a repository surface facility is about 48 miles (NIMA 2001).

- Range 64 is composed of $64 \mathrm{~A}, 64 \mathrm{~B}, 64 \mathrm{C}$ and $64 \mathrm{D}$ and is in the southwestern section of $\mathrm{R}-4806 \mathrm{~W}$. The closest boundary to a repository surface facility is about 27 miles (NIMA 2001).

- Range 65 is composed of $65 \mathrm{~N}$ and $65 \mathrm{~S}$ and is in the south-central section of R-4806W. The closest boundary to a repository surface facility is about 36 miles (NIMA 2001).

\section{B.3 MILITARY TRAINING ROUTES AND AREAS}

Military training routes and areas include LATNs and MTRs (NIMA 2001).

\section{B.3.1 Low Altitude Training Navigation Areas}

The LATN areas associated with the Nevada Test and Training Range are unrestricted airspace areas established on the west, south-central and eastern sides of the NTTR for A-10s and helicopters to practice random selection of navigation points and low altitude tactical formations between 100 and 1,500 feet AGL and at speeds below 250 knots (USAF 1999a, p. 3.1-8). This area is normally used when no airspace is available for this type of training within the NTTR complex. LATNs are not depicted on aeronautical charts; however, local airports and aviation groups have been advised of their existence and associated operations. About 30 to 38 sorties are conducted weekly in the LATN West by Nellis AFB A-10 units and helicopters. The area is in the Beatty corridor (generally the area between China Lake MOAs and the Nellis Test and Training Range restricted areas and the southwestern side of the NTS running generally in a north-south direction) and is approximately 1 mile from a repository surface facility (NIMA 2001). The East LATN is outside the Regional Setting (over 100. miles). The Central LATN is 
used for helicopters only and is approximately 46 miles from a repository surface facility (NIMA 2001).

\section{B.3.2 Military Training Routes}

Military training routes permit military flight training at airspeeds in excess of 250 knots below 10,000 feet AMSL while providing training in low altitude tactics and navigation (USAF 1999a, pp. 3.1-5 to 3.1-8). MTRs are established as IFR routes (IRs) or visual flight rules (VFR) routes (VRs). MTRs in the region have floor segments as low as 100 feet AGL, but they are normally flown between 500 and 1,000 feet AGL. Five MTRs exist within NTTR restricted airspace. Table B-1 is a reproduction of the information provided in Renewal of the Nellis Air Force Range Land Withdrawal (USAF 1999a, Table 3.1-1, p. 3.1-8) and identifies these five routes, the scheduling agency, and portion of the route within restricted airspace, the estimated annual sorties, and the closest distance to the North Portal. 
Table B-1. Military Training Routes that Access Nevada Test and Training Range

\begin{tabular}{|c|c|c|c|c|}
\hline MTR & $\begin{array}{c}\text { Scheduling } \\
\text { Agency }\end{array}$ & NTTR Airspace Accessed & $\begin{array}{c}\text { Approximate } \\
\text { Distance to } \\
\text { North Portal } \\
\text { (miles) }\end{array}$ \\
\hline IR-286 & Nellis AFB & Final segment in R-4806W & 21 & 15 \\
\hline VR-222 & Nellis AFB & Final segment in R-4807 & 550 & 11 \\
\hline VR-1214 & Edwards AFB & Last segment enters R-4807 & 300 & 18 \\
\hline IR 279 & Offutt AFB & $\begin{array}{c}\text { Last segment provides an } \\
\text { entry point to R-4809 }\end{array}$ & 115 & 72 \\
\hline IR 282 & $\begin{array}{c}\text { Mountain Home } \\
\text { AFB }\end{array}$ & $\begin{array}{c}\text { Last segment provides an } \\
\text { entry point to R-4807 }\end{array}$ & 12 & 78 \\
\hline
\end{tabular}

Source: USAF 1999a, Table 3.1-1, p. 3.1-8.

Some of the MTR routes may be used when ingressing/egressing NTTR range target areas, during routine training and exercise. Detailed descriptions of MTRs are provided in Area Planning, Military Training Routes, North and South America (DOD 2002). Note that the section of VR-222 due west of the MGR North Portal is limited to a maximum altitude of 1500 $\mathrm{ft}$. AGL, which represents a deviation from the normal maximum altitude for a three-digit MTR identification.

\section{B.4 R-2508 Complex}

A large area of airspace referred to as the R-2508 Complex exists to the west and southwest of Yucca Mountain and is composed of MOAs and ATCAAs. The R-2508 Complex includes the airspace and associated land presently used and managed by Edwards AFB, National Training Center, Fort Irwin, and Naval Air Warfare Center Weapons Division, China Lake (USAF 2001a, Section 2.3). The airspace is divided both horizontally and vertically with MOAs being overlapped by ATCAAs and restricted areas. Aircraft from the R-2508 Complex accessing the restricted areas in the NTTR use the same access routes skirting around the North Portal through the Sally Corridor and the alternate return routes used by the aircraft from Nellis AFB. The MOAs and ATCAAs combine with R-2508 to form four major work areas (USAF 2001a, Section 7.1.2). Peripheral areas made up of MOAs and ATCAA airspace increases the size of the usable airspace. Typical operations within the R-2508 Complex include (USAF 2001a, Section 7.2):

- Aircraft research and development in all stages of flight

- Operational weapons test and evaluation flights

- Student pilot training

- Air combat maneuvering and proficiency flights

- Civilian test aircraft in direct support of U.S. Department of Defense and/or defense training. 


\section{B.4.1 R-2508 Complex Military Operations Areas}

The four major MOAs within the lateral boundaries of the R-2508 Complex include: Isabella (about 95 miles from the North Portal at Yucca Mountain), Owens (about 78 miles from the North Portal at Yucca Mountain), Saline (about 35 miles from the North Portal at Yucca Mountain) and Panamint (about 36 miles from the North Portal at Yucca Mountain) (NACO 2003a, as measured).

\section{B.4.2 R-2505}

R-2505 airspace is restricted on a continuous basis and is subdivided into five primary ranges. The primary mission of these ranges is the research, development, test, and evaluation of weapons and weapons systems (USAF 2001a, Section 6.2). The closest edge of the R-2505 is about 70 miles from the North Portal at Yucca Mountain (NACO 2003a, as measured).

\section{B.4.3 R-2524}

R-2524 airspace is restricted on a continuous basis. This area includes an ECR that provides a simulated hostile land and sea surface-to-air weapons installation. Targets are available for inert ordnance only (USAF 2001a, Sections 6.4 and 6.5). The closest edge of the R-2524 is about 79 miles from the North Portal at Yucca Mountain (NACO 2003a, as measured).

\section{B.5 R-2508 COMPLEX PERIPHERAL AREAS}

Two peripheral areas within the R-2508 Complex are located within the 100-mile regional setting of Yucca Mountain. These include: Deep Springs ATCAA (56 miles from the North Portal at Yucca Mountain), which provides additional work areas for segregation of military operations from IFR traffic, and Shoshone MOA (200 ft AGL to FL180)/ATCAA (FL180 to FL600) (about 31 miles from the North Portal at Yucca Mountain) (NACO 2003a, as measured) with activities including operational testing and evaluation, air combat maneuvering, low altitude training, and large-scale exercises (USAF 2001a, Section 5.8). 


\section{APPENDIX C}

\section{CIVILIAN, FEDERAL, AND MILITARY AIRPORTS}


INTENTIONALLY LEFT BLANK 


\section{APPENDIX C}

\section{CIVILIAN, FEDERAL, AND MILITARY AIRPORTS}

A number of airports or airfields are located within the regional setting of Yucca Mountain as shown in Figure 6-2 and Figure 6-3. These include military, DOE, and civilian airports.

\section{C.1 Military Airports}

There are three military airports within 100 miles of Yucca Mountain, as shown on Figure 6-3.

\section{C.1.1 Indian Springs Air Force Auxiliary Field}

Indian Springs Air Force Auxiliary Field, located on the southern boundary of R-4806, provides basing for UAV operations, aircraft staging support, and emergency/divert recovery for NTTR operations. It is also the primary training location for the Thunderbirds Air Demonstration Squadron. Table 6-4 lists the flight operations of approximately 4,000 per year. The airfield is about 45 miles from the North Portal at Yucca Mountain (NACO 2003a). Flight activity at this airfield can change as new test and development programs are introduced.

\section{C.1.2 Tonopah Test Range Airfield}

There were 200 flight operations for the Tonopah Test Range Airfield for 2003 (Ragan 2004a). The Tonopah Test Range Airfield is about 66 miles from the North Portal at Yucca Mountain (NACO 2003a).

\section{C.1.3 Nellis Air Force Base}

Nellis AFB is surrounded by the Las Vegas airspace. Total operations during 2003 for Nellis AFB were 32,400 (Ragan 2004a). The Nellis AFB is about 90 miles from the North Portal at Yucca Mountain (NACO 2003a, as measured).

\section{C.1.4 China Lake Naval Air Warfare Center}

Aircraft operations at the China Lake Naval Air Facility (Armitage Field) are greater than 100 miles from the North Portal at Yucca Mountain (NACO 2003a, as measured).

\section{C.2 U.S. Department of Energy Airfields}

There are three DOE airports within the 100-mile regional setting of Yucca Mountain, as shown on Figure 6-3. As discussed below, activity at the NTS airfields has been minimal since the moratorium on underground nuclear testing.

\section{C.2.1 Desert Rock Airport}

Small commuter aircraft that fly staff and equipment to and from various national laboratories and the NTS use the Desert Rock Airport. Helicopters based on the NTS also use this airfield. The Desert Rock Airport is about 27 miles from the North Portal at Yucca Mountain (NACO 2003a). Table 6-4 indicates approximately 4,700 operations per year (Ragan 2004a). 


\section{C.2.2 Pahute Mesa Airstrip}

Pahute Mesa Airstrip is currently used very infrequently. The Pahute airfield is about 18 miles from the North Portal at Yucca Mountain (NACO 2003a, as measured).

\section{C.2.3 Yucca Airstrip}

The Yucca Airstrip has been unused since 1995 (Langendorf 2002). The Yucca Strip is about 20 miles from the North Portal at Yucca Mountain (NACO 2003a, as measured).

\section{C.3 Civilian Airports and Airfields}

Several civilian airports and airfields are within 100 miles of the North Portal at Yucca Mountain. Existing facilities range from small private landing strips to a major international airport. Aircraft activity ranges from 0 to more than 0.5 million operations per year. Figure $6-2$ identifies the location of each of these facilities. The high-volume facilities are located to the south of Yucca Mountain near Las Vegas. Six airports or airfields that are based within reasonable proximity to Yucca Mountain or have high operational levels were selected for detailed discussion in the following sections.

\section{C.3.1 Beatty Airport}

The Beatty Airport, located on the outskirts of the town of Beatty, is a public facility owned by Nye County, Nevada. The airport serves approximately four locally owned single-engine aircraft as well as air taxi service for Beatty and Death Valley National Park.

The Beatty Airport does not have a control tower and is unattended. Pilots are expected to be in radio contact with other aircraft in the area and use visual flight rules during takeoffs and landings. The Beatty Airport is about 21 miles west of the North Portal at Yucca Mountain (NACO 2003a).

\section{C.3.2 Furnace Creek Airport}

The Furnace Creek Airport, located in Death Valley National Park, is a public facility owned by the U.S. Department of Interior, National Park Service. The airport serves two locally owned single-engine aircraft. Single wheel weight limitation is $4000 \mathrm{lbs}$. The runway is only $3065 \mathrm{ft}$ long limiting operations to small aircraft. The Furnace Creek Airport does not have a control tower and is unattended. Pilots are expected to be in radio contact with other aircraft in the area and use visual flight rules during takeoffs and landings. The Furnace Creek Airport is about 37 miles southwest of the North Portal at Yucca Mountain (Ragan 2004a).

\section{C.3.3 Imvite Airfield}

The Imvite Airfield, located in Amargosa Valley, is a private facility owned by IMV, a division of the Floridin Company. The airport serves approximately one locally owned single-engine aircraft. The Imvite airfield is not paved and is only $2600 \mathrm{ft}$ long. Because the Imvite Airfield is privately owned, it is reasonable to forecast that the annual operations are expected to remain approximately the same as current operations. The Imvite Airfield does not have a control tower 
but is attended between 7:00 a.m. and 5:30 p.m. Pilots are expected to be in radio contact with other aircraft in the area and use visual flight rules during takeoffs and landings. The Imvite Airfield is about 28 miles south of the North Portal at Yucca Mountain (Ragan 2004a).

\section{C.3.4 McCarran International Airport}

The McCarran International Airport, located in Las Vegas, Nevada, is a public facility owned by Clark County, Nevada.

McCarran has a control tower attended at all times and is surrounded by the Las Vegas airspace, which is a class of airspace that is characteristic of any airport environment having a high volume of air traffic. This irregular shaped airspace extends from 20-25 nautical miles south and east of Las Vegas/Nellis AFB to the southern boundary of the Desert MOA (Sally Corridor) (NACO 2003a, as measured). Aircraft entering or transiting through this charted airspace must be in contact with, and under the positive control of either Nellis or McCarran radar approach/departure control facilities. The positive protective nature of this airspace enhances flight safety of civilian aviation transiting through this high air traffic density area. McCarran is about 89 miles east-southeast of the North Portal at Yucca Mountain (NACO 2003a, as measured). McCarran International is a Terminal Control Area or Class B Airspace requiring special equipment of all aircraft flying into the McCarran International airspace (NACO 2003a).

\section{C.3.5 North Las Vegas Airport}

The North Las Vegas Airport, located in North Las Vegas, Nevada, is a public facility owned by Clark County, Nevada.

The North Las Vegas Airport has a control tower attended between 5:30 a.m. and 9:30 p.m. The North Las Vegas Airport is surrounded by the Las Vegas airspace. The North Las Vegas Airport is about 82 miles east-southeast of the North Portal at Yucca Mountain (NACO 2003a, as measured). 
INTENTIONALLY LEFT BLANK 


\section{APPENDIX D}

IFR ENROUTE LOW AND HIGH ALTITUDE ROUTES IN THE REGIONAL SETTING 
INTENTIONALLY LEFT BLANK 


\section{APPENDIX D}

\section{IFR ENROUTE LOW AND HIGH ALTITUDE ROUTES IN THE REGIONAL SETTING}

Low Altitude Airways (Victor Airways). Victor Airways are "highways" utilized by both IFR and VFR traffic. These routes are 8 nautical miles wide and generally have a base altitude of $1,200 \mathrm{ft}$ AGL up to but not including 18,000 ft MSL. The airway floor varies to ensure that aircraft operating on the airway remain clear of ground obstructions and have the ability to receive the radio signals from the navigational facilities. These airways are depicted on aeronautical charts as blue shaded lines with a "V," hence the term victor, followed by a number, for example V-820.

Jet Routes. Jet routes serve the same function as the low altitude airways except that they are found at $18,000 \mathrm{ft}$ MSL and above, up to $45,000 \mathrm{ft}$ MSL. The traffic on a jet route is always operating under IFR and is managed by ATC. Jet routes have no specified width. Typical aircraft flying these routes includes airliners, air cargo, corporate jets, and other high performance aircraft.

Jet routes and Victor routes are flown from ground radio navigation aids or VORTACs and navigational fixes (ground based non-directional radio beacons). Aircraft fly either to or from the VORTACs. "Q" routes were introduced in late 2003 (also know are "Area Navigation," or "RNAV," routes). One Q-route is within the regional setting. These routes are designed for high-altitude aircraft flying point-to-point. Route Q13 terminates at the "LIDAT" navigational fix approximately 61 miles northwest of the North Portal.

Table D-1 lists the low and high altitude routes in the regional setting of Yucca Mountain and distances from the North Portal at Yucca Mountain (NACO 2003b and 2003c).

Table D-1. IFR Low and High Altitude Routes

\begin{tabular}{|c|c|}
\hline $\begin{array}{c}\text { Jet Routes and Federal } \\
\text { Airways }\end{array}$ & $\begin{array}{c}\text { Approximate Centerline } \\
\text { Distance from North Portal, } \\
\text { Yucca Mountain }\end{array}$ \\
\hline $\mathrm{J9}$ & 86 \\
\hline $\mathrm{J} 58-\mathrm{J} 80$ & 82 \\
\hline $\mathrm{J} 72$ & 88 \\
\hline $\mathrm{J} 76$ & 88 \\
\hline $\mathrm{J} 86$ & 14 \\
\hline $\mathrm{J} 92$ & 11 \\
\hline $\mathrm{J} 100$ & 86 \\
\hline $\mathrm{J} 110$ & 41 \\
\hline $\mathrm{J} 146$ & 86 \\
\hline $\mathrm{J} 148$ & 95 \\
\hline V105 & 16 \\
\hline V135 & 16 \\
\hline V244 & 85 \\
\hline V394 & 88 \\
\hline V538 & 89 \\
\hline Q13 & 61 \\
\hline
\end{tabular}

Source: NACO 2003a, for V routes, as measured.

NACO $2003 b$, for $J$ routes, as measured, and NACO 2003c, for Q Routes, as measured. 


\section{D.1 J-110 Jet Route}

Route $\mathrm{J}-110$ is an east-west jet route terminating at the Oakland (California) VORTAC via Monterey (California) VORTAC, via Clovis VORTAC, via Boulder City VORTAC and on to the east. Typical flights to/from Oakland, San Francisco, and other western cities to Las Vegas and beyond fly this route. A portion of the route crosses the R-2508 complex. This portion of $\mathrm{J}-110$ is normally unavailable to aircraft during daylight hours Monday through Friday (NACO $2003 \mathrm{~b}$, as identified on the chart).

\section{D.2 J-86 Jet Route}

Route J-86 starts at the Beatty VORTAC, intersects with J-110 at the FUZZY fix west of the Boulder City VORTAC, and generally heads to the southeast to El Paso VORTAC and beyond. The centerline distance from the North Portal at Yucca Mountain is approximately 14 miles (NACO 2003b, as measured). As noted in (Shively 2002), the FAA allows flights to use the entire width between R-2508 and R-4808/R-4807. Therefore, the closest point aircraft can fly in this jet route is about 6 miles, which is the closest distance from the North Portal at Yucca Mountain to the R-4808S boundary (see Table 6-1).

\section{D.3 J-92 Jet Route}

Route J-92 continues toward the Coaldale VORTAC and then on to Reno, NV (see Figure 6-2). The centerline distance from the North Portal at Yucca Mountain is approximately 11 miles (NACO 2003b, as measured). According to the FAA, civilian aircraft are allowed to use the airspace between the R-2508 and R-4800 restricted areas (Shively 2002). Therefore, the closest point aircraft can fly in this jet route is about 6 miles, which is the closest distance from the North Portal at Yucca Mountain to the R-4808S boundary (see Table 6-1).

\section{D.4 V-105/135 Airway}

This airway begins south of the NTS, heads northwest paralleling the NTTR, and splits off (see Figure 6-2). V-105 continues to the Coaldale VORTAC and then on to Reno, NV. V-135 heads northeast and terminates at the Tonopah Airport. The centerline distance from the North Portal at Yucca Mountain is approximately 16 miles (NACO 2003c, as measured). 
APPENDIX E

\section{CIVILIAN AND MILITARY ACCIDENTS IN THE REGIONAL SETTING AND} SELECTED MILITARY ACCIDENTS 
INTENTIONALLY LEFT BLANK 


\section{APPENDIX E \\ CIVILIAN AND MILITARY ACCIDENTS IN THE REGIONAL SETTING AND SELECTED MILITARY ACCIDENTS}

Details for the civilian aircraft accidents are shown in Table E-1; details for the Air Force aircraft accidents identified in Figure 6-4 are shown in Table E-2. A criterion for selection of these accidents includes a pilot and/or passenger fatality. Several of the later events were preliminary reports, but were added for completeness.

Table E-1. Civilian Aircraft Accidents from 1993 to 2003

\begin{tabular}{|c|c|c|c|}
\hline Rec.\# & FAR Part & Event Date & City \\
\hline 1 & 091 & 19-Jun-93 & HENDERSON \\
\hline 2 & 135 & 12-Jul-93 & LAS VEGAS \\
\hline 3 & 091 & 19-Nov-93 & LAS VEGAS \\
\hline 4 & 091 & 24-Sep-94 & LAS VEGAS \\
\hline 5 & 091 & 03-Dec-94 & NORTH LAS VEGAS \\
\hline 6 & 091 & 25-Sep-97 & SANDY VALLEY \\
\hline 7 & 091 & 3-Apr-99 & INDIAN SPRINGS \\
\hline 8 & 091 & 20-Aug-99 & LAS VEGAS \\
\hline 9 & 135 & 14-Oct-99 & NORTH LAS VEGAS \\
\hline 10 & 091 & 28-Apr-00 & NORTH LAS VEGAS \\
\hline 11 & 091 & 29-Aug-00 & LAS VEGAS \\
\hline 12 & 091 & $13-$ Oct-00 & HENDERSON \\
\hline 13 & 091 & 19-May-01 & NORTH LAS VEGAS \\
\hline 14 & 091 & $30-$ Oct-01 & MT CHARLESTON \\
\hline 15 & 091 & 26-Jan-02 & NORTH LAS VEGAS \\
\hline 16 & 091 & 4-Apr-03 & NORTH LAS VEGAS \\
\hline 17 & 091 & 19-May-03 & JEAN \\
\hline 18 & 091 & 14-Dec-03 & TONOPAH \\
\hline 19 & 091 & $25-\mathrm{Dec}-03$ & NORTH LAS VEGAS \\
\hline
\end{tabular}

Source: Ragan 2004b. 
Table E-2. Air Force Class "A" Accidents in Nevada, 1993-2003

\begin{tabular}{|l|l|l|l|l|l|l|}
\hline Record \# & $\begin{array}{c}\text { Mishap } \\
\text { ID }\end{array}$ & \multicolumn{1}{|c|}{ Aircraft } & Mishap Base & $\begin{array}{c}\text { Mishap } \\
\text { Latitude }\end{array}$ & $\begin{array}{c}\text { Mishap } \\
\text { Longitude }\end{array}$ & \multicolumn{1}{c|}{ Mishap Description } \\
\hline 1 & 320775 & N/A & Nellis AFB NV & $360030 \mathrm{~N}$ & $1152755 \mathrm{~W}$ & Controlled flight into or toward terrain \\
\hline 2 & 321406 & F-16 & Nellis AFB NV & $365925 \mathrm{~N}$ & $1144020 \mathrm{~W}$ & Loss of control - Inflight \\
\hline 3 & 321594 & F-16 & Nellis AFB NV & $373012 \mathrm{~N}$ & $1161616 \mathrm{~W}$ & Controlled flight into or toward terrain \\
\hline 4 & 321789 & F-16 & Nellis AFB NV & $371106 \mathrm{~N}$ & $1152624 \mathrm{~W}$ & Controlled flight into or toward terrain \\
\hline 5 & 322073 & F-16 & Nellis AFB NV & $363520 \mathrm{~N}$ & $1154000 \mathrm{~W}$ & Controlled flight into or toward terrain \\
\hline 6 & 324376 & Unknown & Nellis AFB NV & $361500 \mathrm{~N}$ & $1150100 \mathrm{~W}$ & Abnormal runway contact \\
\hline 7 & 325405 & Unknown & Nellis AFB NV & $372136 \mathrm{~N}$ & $1151130 \mathrm{~W}$ & Undershoot/overshoot \\
\hline 8 & 300524 & HH-60 & Nellis AFB NV & $365530 \mathrm{~N}$ & $1154004 \mathrm{~W}$ & Midair/near midair collision \\
\hline 9 & 301262 & F-15 & Nellis AFB NV & $375500 \mathrm{~N}$ & $1160100 \mathrm{~W}$ & Midair/near midair collision \\
\hline 10 & 301320 & Unknown & Nellis AFB NV & $361400 \mathrm{~N}$ & $1150100 \mathrm{~W}$ & $\begin{array}{l}\text { System/component failure or malfunction } \\
\text { (powerplant) }\end{array}$ \\
\hline 11 & 302356 & F-15 & Nellis AFB NV & $375100 \mathrm{~N}$ & $1154100 \mathrm{~W}$ & Loss of control - Inflight \\
\hline 12 & 302372 & F-16 & Nellis AFB NV & $365844 \mathrm{~N}$ & $1143107 \mathrm{~W}$ & Midair/near midair collision \\
\hline 13 & 304019 & Unknown & Nellis AFB NV & $365450 \mathrm{~N}$ & $1134941 \mathrm{~W}$ & Controlled flight into or toward terrain \\
\hline 14 & 305391 & F-15 & Nellis AFB NV & $374600 \mathrm{~N}$ & $1150200 \mathrm{~W}$ & $\begin{array}{l}\text { System/component failure or malfunction } \\
\text { (powerplant) }\end{array}$ \\
\hline 15 & 305489 & A-10 & Nellis AFB NV & $372615 \mathrm{~N}$ & $1162353 \mathrm{~W}$ & \\
\hline 16 & 306405 & F-15 & Nellis AFB NV & $370402 \mathrm{~N}$ & $1143623 \mathrm{~W}$ & Midair/near midair collision \\
\hline 17 & 323337 & Unknown & $\begin{array}{l}\text { Tonopah AFS } \\
\text { NV }\end{array}$ & $375419 \mathrm{~N}$ & $1165006 \mathrm{~W}$ & $\begin{array}{l}\text { System/component failure or malfunction } \\
\text { (non-powerplant) }\end{array}$ \\
\hline 18 & $11 / 2003$ & A-10 & Nellis AFB NV & $3645 \mathrm{~N}$ & $11527 \mathrm{~W}$ & Unknown \\
\hline
\end{tabular}

${ }^{\mathrm{a}}$ Format is, for example, $360030 \mathrm{~N}$ is $36^{\circ} 00^{\prime} 30^{\prime \prime} \mathrm{N}$

Source: McGregor 2004; Wood 2004, pp. 6-7. 
APPENDIX F

\section{NATURAL BARRIERS (MOUNTAINS)}


INTENTIONALLY LEFT BLANK 


\section{APPENDIX F}

\section{NATURAL BARRIERS (MOUNTAINS)}

The Nevada Test and Training Range Chart, (NIMA 2001) identifies natural barriers for the MGR North Portal. For the LATN areas to the west and VR-222 to the west, the Yucca Mountain ridgeline provides a visual separation from the valley where military flights occur. Also, as the LATN and VR-222 are limited to flights below 1,500 ft and are typically flown at $500 \mathrm{ft}$ to $1,000 \mathrm{ft} \mathrm{AGL}$, the Yucca Mountain ridgeline provides a natural barrier to aircraft crash hazards.

The record of flight activity from the FAA (Ragan 2002) does not count all of the flights below $10,000 \mathrm{ft}$ MSL, where an undetermined number of general aviation flights are conducted. Of these, some are below 1,200 $\mathrm{ft}$ AGL in uncontrolled Class G airspace. At this altitude above the valley floor to the west or southwest of Yucca Mountain (NIMA 2001) at Crater Flat (elevation up to $4,000 \mathrm{ft}$ ), an airplane would still be below the crest of Yucca Mountain (around $4800 \mathrm{ft}$ ). Therefore, there is no hazard to the Yucca Mountain facilities from general aviation aircraft below $1,200 \mathrm{ft}$ to the west or southwest.

The elevation of the Yucca Mountain facilities is about 3,700 $\mathrm{ft}$ (NIMA 2001). Five or more miles to the south of the North Portal in the southwest corner of the NTS (R-4808S) is an area around Fortymile Wash (elevation up to 3,000 ft) where aircraft flying at 1,200 ft AGL could be higher in altitude and possibly in view of the Yucca Mountain facilities. However, civilian use of R-4808S is not permitted below FL200 (that is, below about 20,000 ft MSL) (USAF 1996, Section 1.27). Therefore, civilian air traffic below $10,000 \mathrm{ft}$ MSL in the lower reaches of Fortymile Wash is at least 11 miles from the North Portal (NIMA 2001). Moreover, there is a number of obstructions, such as Busted Butte to the south of the North Portal (elevation 4,266 ft) and Little Skull Mountain to the southeast of the North Portal (elevation 4,666 ft) that help reduce the possibility of an aircraft impacting North Portal facilities from the lower reaches of Fortymile Wash (elevation below about 2,800 ft) (NIMA 2001). North of Busted Butte and south of the North Portal, Fran Ridge runs north and south at about 3,800 ft elevation and provides additional protection from aircraft to the southeast of the site. The great distance and topographical obstructions that separate the southern reaches of Fortymile Wash from the Yucca Mountain site make it difficult to imagine that an accident initiated there at an altitude below $1,200 \mathrm{ft}$ AGL could terminate in a crash into the Yucca Mountain facilities.

Civilian flight is not permitted in R-4808N (USAF 1996, Section 1.1). While civilian flight is technically permitted in EC South under limited circumstances (USAF 1996, Sections 1.1, 1.24), in practice, there is very little civilian traffic in this area. Subsequently, the hazard posed by general aviation aircraft below 1,200 ft AGL near Yucca Mountain is determined to be negligible.

Military flights below $10,000 \mathrm{ft}$ MSL are conducted on military training routes VR-222, VR1214 , and $\mathrm{IR}-286$. These military training routes are normally flown between $500 \mathrm{ft}$ and $1,000 \mathrm{ft}$ AGL. The section of VR-222 due west of the North Portal has a maximum altitude of $1,500 \mathrm{ft}$ AGL. VR-1213 is also limited to 1,500 $\mathrm{ft}$ AGL. This places the aircraft low enough that the 
topographic barriers discussed previously will severely limit any hazard they might otherwise pose to Yucca Mountain surface facilities. The altitude variation between the MGR ridgeline above the North Portal and the centerline of the VR-222 MTR is approximately 1,400 $\mathrm{ft}$ (the valley floor just east of the MTR is $3,459 \mathrm{ft}$ and the crest of the Yucca Mountain ridge line is $4,846 \mathrm{ft}$ ), providing a natural barrier to deviant aircraft flying the MTR and a well-defined flight path through the valley to the west of the Yucca Mountain ridgeline for VFR flight. Military flights below $10,000 \mathrm{ft}$, therefore, do not pose a hazard to the MGR. 